HID 46 (2019)

\title{
EL DESARROLLO DE LA ALMONEDA DE LOS BIENES MUEBLES DE ISABEL LA CATÓLICA ${ }^{1}$
}

\section{THE DEVELOPMENT OF THE AUCTION OF THE PERSONAL PROPERTY OF ISABELLA I OF CASTILE}

\author{
José JULIO MARTÍN BARBA \\ UESD. Madrid \\ jotesco@gmail.com ORCID: https://orcid.org/0000-0001-8916-7357
}

RESUMEN: Pocos días antes de morir Isabel I de Castilla dictó su testamento, en el cual mandaba a sus testamentarios, encabezados por su esposo, que vendieran todos sus bienes para saldar sus deudas. Aunque la reina marcó un año natural como plazo límite, lo cierto es que el proceso de liquidación se prolongó por mucho más tiempo. En este trabajo presentamos la sucesión de las distintas fases a través de los documentos que emitió Fernando el Católico para formalizar la almoneda, conservados en el Archivo General de Simancas.

PALABRAS ClAVE: Almoneda; Isabel la Católica; Fernando el Católico; Juan Velázquez; Sancho de Paredes.

ABSTRACT: Few days before her death, Isabel I of Castile made her last will and testament, in which she ordered the executors, headed by her husband, to sell all her goods in order to pay back her debts. Even though the queen determined that the deadline should be within the period of a calendar year, the fact is that the liquidation process extended during a much longer time. In this work we offer the sequence of the different phases, reflected in the documents that were issued by Fernando the Catholic to formalize the auction, which are conserved in the Archivo General de Simancas.

KEYwORDS: Auction; Isabella I of Castile; Ferdinand II of Aragon; Juan Velázquez; Sancho de Paredes.

Recibido: 26-11-2018; Aceptado: 5-2-2019; Versión definitiva: 193-2019.

1. Abreviaturas utilizadas: $\mathrm{AGS}=$ Archivo General de Simancas; $\mathrm{PTR}=$ Patronato Real; $\mathrm{CSR}=$ Casa y Sitios Reales; $\mathrm{CCA}=$ Cámara de Castilla; $\mathrm{CED}=$ libro de cédulas; $\mathrm{CMC}=$ Contaduría Mayor de Cuentas; $1 \mathrm{EP}=1^{\mathrm{a}}$ Época; LEG. = legajo. Quiero agradecer a todo el personal del Archivo General de Simancas su trabajo y disponibilidad para ayudar en todo momento.

Copyright: (C) Editorial Universidad de Sevilla. Este es un artículo de acceso abierto distribuido bajo los términos de la licencia de uso y distribución Creative Commons Reconocimiento-No-ComercialSinObraDerivada 4.0 (CC BY-NC-ND 4.0) 
La documentación real que contiene el proceso de venta en almoneda de los bienes de Isabel la Católica la encontramos en el Archivo General de Simancas, en la sección de la Contaduría Mayor de Cuentas, $1^{a}$ Época, en los legajos 81, 178, 189, 190, 192 y 959. El primero que se acercó a esta documentación para estudiar la "biblioteca" de la reina fue el historiador Diego Clemencín, cuyo trabajo fue publicado en 1820 en la obra Elogio de la reina católica doña Isabel ${ }^{2}$. En el siglo siguiente, el historiador del arte Francisco Javier Sánchez Cantón trabajó con estos documentos para su estudio sobre el políptico de Isabel la Católica, con el que publicó un par de artículos sobre este asunto, primicia de una obra mucho más amplia que vio la luz años más tarde, titulada Libros, tapices y cuadros que coleccionó Isabel la Católica. Pero desde luego el que aportó un progreso significativo al estudio de la almoneda de la reina Isabel fue Antonio de la Torre y del Cerro, quien transcribió en su obra Testamentaría de Isabel la Católica multitud de documentos contenidos en dichos legajos, sacando a la luz los que consideró más importantes, aunque no todos. En los últimos años han visto la luz excelentes estudios sobre distintos objetos que pertenecieron a la reina Isabel, para los cuales sus autores han acudido a esta documentación de la almoneda: Elisa Ruiz ha trabajado sobre los libros de la Católica, Miguel Ángel Zalama sobre sus joyas, tapices y pinturas ${ }^{3}$ o Víctor Pérez Álvarez los relojes. Aunque hace unos años el historiador Luis Fernández Martín hizo un estudio general sobre la almoneda, donde enumeró los distintos compradores y objetos comprados ${ }^{4}$, creo que nadie ha presentado un estudio sobre el desarrollo de la venta de todos estos objetos a partir de la documentación real, proceso que se extendió a lo largo de más de ocho años. Sobre esto versará este trabajo.

El 12 de octubre de 1504 en Medina del Campo, Isabel la Católica dictó sus últimas voluntades a su secretario Gaspar de Grizio, documento conservado en el Archivo General de Simancas. En él, la reina de Castilla, después de encomendar su alma a Dios y a los santos, hacer profesión de fe y detallar el lugar y modo de su entierro y exequias, mandó que todas sus deudas fueran canceladas para descargo de su conciencia. Un año natural fue el plazo que marcó para que sus testamentarios cumplieran su última voluntad ${ }^{5}$ de la siguiente manera:

E para cumplir y pagar las debdas e cargos susodichos, e las otras mandas e cosas en este mi testamento contenidas, mando que mis testamentarios tomen luego e distribuyan todas las cosas que yo tengo en los Alcáçares de la cibdad de Segovia, e todas las ropas e joyas e otras cosas de mi cámara e de mi persona, e qualesquier otros bienes muebles que yo tengo donde podieren ser avidos ${ }^{6}$.

\footnotetext{
2. Político e historiador, miembro de la Real Academia de la Historia. Cf. Clemencín 2004.

3. Cf. Ruiz 2004, 2005; Zalama 2005b; 2006a; 2006b; 2008; 2014; Pérez 2013; 2015.

4. Cf. Fernández 1980; 1981, pp. 63-121.

5. Testamento y Codicilo 2013, p. 26.

6. Ibid., p. 35.
} 
Esto no era extraño. En la Baja Edad Media fue habitual que reyes, nobles y obispos dispusieran en su testamento pagar sus deudas a través de lo obtenido con la venta de sus pertenencias. Para ello nombró como ejecutores testamentarios a su esposo -el rey Fernando-, al cardenal Cisneros, a sus contadores mayores -Antonio de Fonseca y Juan Velázquez-, a su confesor -fray Diego de Deza- y a su secretario y contador -Juan López de Lezárraga $-^{7}$. Y de entre estos, mandó que fuera Juan Velázquez quien recibiera todos sus bienes y se encargara de su venta:

ltem mando, que para cunplir e pagar las debdas e cargos e otras cosas en este mi testamento contenidas, se pongan en poder del dicho Juan Velázquez, mi testamentario, todas mis ropas e joyas e cosas de oro e plata, e otras cosas de mi camara e persona, e lo que yo tengo en otras partes qualesquier ${ }^{8}$.

El 26 de noviembre al mediodía la reina abandonaba este mundo en la mencionada ciudad castellana, con cincuenta y tres años de edad y faltándole pocos días para cumplir los treinta de reinado. Su esposo hizo llegar a todos los lugares del reino una carta por él firmada en la que se comunicaba la luctuosa noticia y se ordenaba celebrar sin ostentación funerales por su alma y alzar pendones en honor de la nueva reina de Castilla, doña Juana, tal como había ordenado en su testamento. Al día siguiente de madrugada salió la regia comitiva fúnebre hacia Granada, cumpliendo así otra de sus mandas testamentarias que pedía ser enterrada allí. No llegaron sus restos mortales a dicha ciudad hasta el 17 de diciembre 9 . El rey no acompañó el cortejo fúnebre, sino que se retiró al monasterio jerónimo de la Mejorada para cumplir con los nueve días de duelo, según la costumbre castellana. El 8 de diciembre salió el monarca de dicho cenobio y el día 14, aposentado en la ciudad de Toro, firmó con los testamentarios la primera real cédula referida a la venta en almoneda de los bienes de su esposa. El último documento sobre la almoneda que firmó el rey Fernando fue la carta de finiquito extendida a Juan Velázquez en diciembre de 1512. Habían transcurrido ocho largos años.

\section{TORO}

Ese primer documento de Fernando sobre la almoneda fue una real cédula dirigida a Violante de Albión, criada de la reina, en la que mandaba que entregase a Juan Velázquez de Cuéllar, contador mayor, los bienes muebles de la soberana que tenía a su cargo para cumplir sus últimas voluntades. La segunda cédula real, firmada por los mismos albaceas testamentarios y fechada el 30 de diciembre en la misma ciudad, ordenaba a Sancho de Paredes y a su esposa Isabel Cuello, ca-

7. Ibid., p. 35-36.

8. Ibid., p. 37.

9. Azcona 1993, pp. 941-946. 
mareros de la reina ${ }^{10}$, que entregasen igualmente todas las rropas e hornamentos e joyas e piedras e perlas e oro e plata e camas e tapiçería e sedas e brocados e paños e rropa blanca e todas las otras cosas, de qualquier valor e calidad de la reina y que de todo lo entregado se tomara buena nota ${ }^{11}$.

En Toro el 21 de diciembre se comenzó a trabajar. Se dice que fue en el alcázar de esta ciudad donde Juan Velázquez y el escribano de la cámara, Suero de Cangas $^{12}$, con sus oficiales respectivos, a medida que iban llegando las arcas con las propiedades reales, levantaban acta de la apertura, inventariaban su contenido y ciertos tasadores ponían precio a cada uno de los objetos, que quedaba anotado en la relación de cosas entregadas. Arduo trabajo fue este si contemplamos la cantidad de pliegos de todo lo recibido. Se abrieron aquí dieciséis arcas cuyo contenido lo hallamos en el legajo $81^{13}$ y agrupado en partidas según su materia en el legajo $192^{14}$.

El ingente número de acémilas utilizadas para transportar las cosas de la reina a Toro desde los palacios de Medina del Campo y Arévalo nos hace imaginar la enorme cantidad de objetos transportados: nada menos que ciento treinta y un mulos, por los que se pagaron 36985 maravedís ${ }^{15}$. Viendo el rey el formidable patrimonio de la reina que llegaba a Toro ${ }^{16}$, mandó por cédula real a los contadores mayores de cuentas y sus lugartenientes que llevaran control tanto de los objetos recibidos por Juan Velázquez - cargo-, así como el dinero obtenido con la venta de los mismos en las sesiones de almoneda, que debía entregar al tesorero del rey -data-; asimismo ordenaba que, una vez que no quedara en su haber ni objetos que vender, ni numerario que ingresar, se le extendiera la carta de finiquito para

10. El oficio de camarero mayor comportaba el cuidado, organización y custodia de la cámara de la reina y sus pertenencias. Sancho de Paredes, junto a su esposa comenzaron como tenientes de camarero en 1498. A partir de 1502 aparecen asentados en nómina real ya no como tenientes de camarero, sino como camareros ordinarios de la reina. González Marrero 2005, pp. 65-68.

11. Documentos 1 y 3 .

12. Dentro de los oficios dependientes del camarero estaba el escribano de la cámara "que llevaba la cuenta de gastos, los libros de inventario y, junto con el personal responsable, el control del contenido de las arcas numeradas donde se guardaban las ropas, armas y otros objetos. El escribano era el segundo oficio en importancia tras el camarero": Ladero Quesada 1998, pp. 340-341. Cf. González Marrero 2005, pp. 74-75.

13. AGS,CMC,1EP,LEG.81, pl. 1. Torre y del Cerro p. 5.

14. "Que se carga a Juan Velazques e a Juan de San Román, su criado en su nombre, las cosas de oro que adelante serán declaradas las quales se hallaron en las arcas de que la reyna nuestra señora que aya santa gloria tenía las llaves, las quales dichas llaves el dicho Juan Velázquez e Juan Lópes, contador e secretario de su alteza, tomaron en su poder e abrieron las dichas arcas e se hallaron en ellas las dichas cosas de oro que son las siguientes". AGS,CMC,1EP,LEG.192, pl. 1.

15. Documento 2 .

16. AGS,CMC,1EP,LEG.81. Este es el orden de los encabezamientos de los distintos cargos de Sancho de Paredes entregados a Juan de Velázquez: un cargo de plata, otro cargo de joyas de oro, otro más de joyas de oro, otro de oro hilado e sirgos de colores e bordaduras e oro tirado, otro cargo de perlas, oro, piedras, plata, otro de perlas y aljófar, otro de anbar, otro de cuenta de corales, otro de retablos de lienços e tablas de devoçion, otro de libros, otro de sedas y brocados, otro titulado vestidos de brocado e seda e paño, otro de ropa de vestir y ropa blanca, otro de lienzos, ropa blanca y manteles, otro de bonetes, sonbreros y almayzales y guantes, otro de guarniciones de mulas e cavallos, otro de chamelotes e tafetanes e guarniciones de ornamentos e texillos, etc., otro de cosas menudas, otro de ornamentos y tapicería, otro de hornamentos, y por último tres cargos consecutivos de tapiçería. 
quedar libre para siempre de dicho cargo ${ }^{17}$. Nunca pudieron imaginar ni uno ni otro que este proceso se iba a prolongar tanto tiempo.

Aunque nada sabemos del modo de vender los objetos en la almoneda, sí conocemos la relación de cosas vendidas, el precio y los compradores, gracias a las cuentas de Juan Velázquez, encargado por el rey para la recepción y venta de las cosas de la cámara de la reina nuestra señora que santa gloria haya-fórmula que se repite insistentemente en estos documentos-, libros que se han conservado en el mencionado Archivo.

Durante los primeros días del año nuevo comenzaron a llegar a Toro los procuradores de las ciudades llamados a Cortes, convocadas para cumplir otro mandato contenido en el testamento de la reina. Aunque Isabel había instituido a su hija Juana heredera universal de la Corona de Castilla, había nombrado a su esposo Fernando gobernador y administrador del reino, en caso de que su hija no quisiere o pudiere entender en la gobernación. Previendo además que su sucesora legítima no estaría en Castilla a la hora de su muerte porque estaba en Flandes, dispuso que el rey, antes que comiençe a usar de la dicha gouernaçión, ante todas cosas, aya de jurar e jure en presençia de los prelados e grandes e caualleros e procuradores de los dichos mis reynos [...] que bien e devidamente regirá e gouernará los dichos mis regnos ${ }^{18}$. Aprovechó el rey viudo la presencia de los procuradores que iban a jurar a Juana como reina de Castilla y a él como gobernador y administrador, para dar comienzo la almoneda, de modo que si comenzaron las sesiones de las Cortes el día de la Epifanía y se prolongaron hasta mediados de febrero, encontramos nóminas de venta de cosas de la cámara de la reina a partir del 10 de enero $^{19}$. Y mientras unos vendían, otros iban tasando la multitud de objetos de todo tipo que estaban sin apreçiar como nos muestran los legajos 178 y $192^{20}$.

Después de las Cortes, debió ser tan enorme la cantidad de cosas que no se habían vendido que el rey autorizó a los camareros Sancho de Paredes e Isabel Cuello $^{21}$ de una parte, y a Violante de Albión ${ }^{22}$ de otra, a vender por su cuenta las joyas y otras cosas que habían tenido a su cargo por el precio que estaban tasadas en los libros de cámara de la reina, tras lo cual entregarían el dinero al tesorero para descargar así a Juan Velázquez el objeto o su importe.

Una de las partidas más numerosa fue la de piezas textiles: tapices, ornamentos, brocados, reposteros, etc., sobre la cual el rey determinó, en varias ocasiones a lo largo de la almoneda, la donación a iglesias e monasterios, para las cosas necesarias al culto divino del Sancto Sacramento, asi como para la custodia e ornato del sagrario ${ }^{23}$, tal como había dispuesto su esposa en el testamento. El primer

17. Documento 4.

18. AGS,PTR,LEG,30-2, f. 5v. Testamento y Codicilo 2013, p. 32.

19. AGS,CMC,1EP,LEG, 178, f. 80. 1505, enero, 10 Toro.

20. AGS,CMC,1EP,LEG,192. Encontramos en este legajo tasaciones de joyas, libros y retablos realizadas en el primer trimestre de 1505, entre ellos, el políptico de Isabel la Católica. Cf. Sánchez Cantón 1930, pp. 98-101.

21. Documento 5.

22. AGS,CMC,1EP,LEG, 178, f. 107. 1505, febrero, 16. Toro.

23. AGS,PTR,LEG,30-2, f. 8r. Testamento y Codicilo 2013, p. 36. 
mandato de este estilo son las dos nóminas del 13 y el 14 de marzo de 1505 que se entregaron a Pero García de Atienza, limosnero de la reina nuestra señora, para llevar a la capilla real de Granada ${ }^{24}$

\section{SEgOVIA}

El 10 de abril de 1505, Fernando el Católico, en previsión de su próximo traslado a Segovia, expidió otra cédula a Rodrigo de Tordesillas, el tesorero del alcázar de aquella ciudad, para que hiciera entrega a Juan de Velázquez de todos los objetos que tenía a su cargo ${ }^{25}$. La Corte partió desde Toro el 29 de abril camino de Segovia, pero se detuvo cinco días en Arévalo.

De los bienes de la reina Isabel que se habían reunido en Toro, una gran parte se trasladó a Arévalo y el resto a Segovia, a tenor de la nómina de pago expedida a Pedro Patiño, teniente de mayordomo, en concepto de alquiler de las acémilas y carretas que transportaron todos aquellos objetos de la cámara de la reina. Podemos imaginar todo lo que quedaba por subastar si nos fijamos en el número de carretas alquiladas que se utilizaron: en Arévalo quedó la façienda de la reina a cargo de Sancho de Paredes, para la que se precisaron dieciocho carretas en el traslado; y hasta Segovia siguieron otras siete carretas con la façienda que estaba a cargo de los monteros y cuatro más con los objetos a cargo de Violante de Albión. Un alto precio hubo de pagar el tesorero real por el traslado, nada menos que 30.608 maravedís por los veintinueve carros ${ }^{26}$. El rey continuó camino y llegó a Segovia el 8 mayo, donde permaneció con la Corte hasta mediados de octubre ${ }^{27}$.

Todo quedó almacenado en el palacio real de Arévalo, esperando a que Sancho de Paredes hiciera el cargo. Así se hizo según vemos en el leg. 81 de la Contaduría Mayor de Cuentas, entre mayo y julio de 1505, Sancho de Paredes fue entregando todo tipo de piezas y objetos, a Baltasar de San Román (hombre de cámara de la reina), Pedro de Saravia (mozo de espuelas y portero de cocina) y Lope de León (comprador de las cosas de cámara), que actuaron en nombre de Juan Velázquez. Los escribanos de la cámara fueron cuidadosos y, a través de los propios libros de cámara de Sancho de Paredes, fueron cargando uno a uno cada objeto a Juan Velázquez, siguiendo el mismo orden, como podemos comprobar en sus libros.

Después de una primera fase de ventas en las que parece que no ingresaron todo el numerario que esperaban, el rey y los testamentarios tomaron cuatro medidas importantes para dar salida al enorme volumen de objetos: la primera, rebajar los precios de las joyas, siendo encargada la retasación a Diego Cano, escribano de la cámara de la reina ${ }^{28}$. La segunda, fundir en la Casa de la Moneda de Segovia

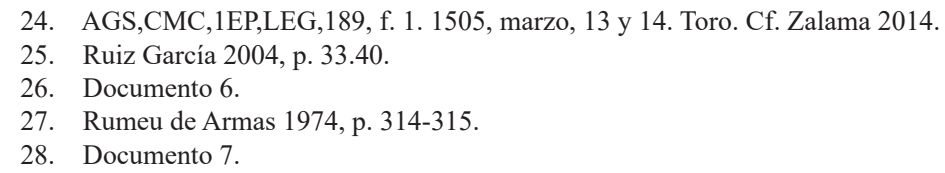


una gran parte de cadenas, cintas, brocados y otros objetos que fueron desechados para la venta por estar deteriorados o anticuados, pero que al estar realizados con oro se podía obtener el beneficio del material noble ${ }^{29}$. La tercera, hacer ornamentos litúrgicos con la ingente cantidad de "ropas de vestir" tanto de la reina, como del príncipe Juan, que habían quedado almacenadas en las cámaras de la reina después de su muerte, para enviarlos a lugares píos, iglesias y monasterios ${ }^{30}$. Y la cuarta y última, completar el pago al rey Manuel I de Portugal de la dote de la infanta María, cuarta hija de los Reyes Católicos, con la que se había casado en segundas nupcias, después de morir la primera esposa, hermana mayor de esta ${ }^{31}$. Quiso en este momento desempeñar la corona y el collar de balajes de la reina que estaban en Valencia, pero solo tenía numerario para la corona, que mandó que se la trajeran ${ }^{32}$. En abril ya tenía también el collar.

Consideramos que las prisas por acabar la almoneda ${ }^{33}$ venían motivadas por la decisión tomada por Fernando de casarse en segundas nupcias con la infanta francesa Germana de Foix. A través de este matrimonio político pretendía aliarse con Luis XII de Francia en el dominio sobre Nápoles y bloquear así la posibilidad de que lo hiciera con Felipe de Habsburgo y el emperador Maximiliano. Tras unas largas negociaciones realizadas por sus embajadores en Francia, la boda se celebró por poderes en Blois el 19 de octubre, siendo representado por el conde de Cifuentes. Tardarían todavía cinco meses en verse por primera vez. Aunque esta unión a Fernando le vino bien para defender sus derechos sobre la región italiana, le granjeó el descontento de los castellanos, que consideraron este matrimonio como un ultraje a la memoria de Isabel.

Y así, recién casado, pero sin cónyuge a su lado, se trasladó a Salamanca con toda la Corte para negociar con los embajadores de su yerno Felipe y su consuegro Maximiliano. También se trasladaron a la ciudad del Tormes los bienes de la cámara de la reina que no se habían vendido en Segovia. El hecho de que en la traslación los acemileros parasen en Arévalo para tomar los objetos que allí estaban almacenados, nos induce a pensar que el rey quiso concluir la almoneda en una última sesión salmantina ${ }^{34}$.

29. AGS,CMC,1EP,LEG,189, f. 19. 1505, julio, 27. Segovia. Encontramos aquí catorce pliegos que enumeran los objetos que se fundieron, por los que se obtuvo $937.370 \mathrm{mrs}$.

30. Documentos 8 y 9 .

31. AGS,CMC,1EP,LEG,178, fol. 303. 1505, junio, 30. Segovia: "Por quanto yo e los otros testamentarios de la Serenísima rreyna doña Ysabel mi muger que aya santa gloria avemos acordado que de las joyas de su señoría quedaron para cumplimiento de su ánima y testamento se den al serenísimo rey de Portugal don Manuel, mi muy amado hijo, para en cuenta e pago de la dote que ovo de aver con la serenísima rreyna doña María mi muy cara e muy amada hija, su mujer, valor de 10.000 ducados en joyas de las que de su señoría quedaron”. El cargo de estas joyas está en AGS,CMC,1EP,LEG,189, f.1, pl.55-56.

32. Zalama 2006b.

33. Dice el rey en una real cédula fechada el día 22 de julio de 1505 que "al cumplimiento del testamento de su Señoría conviene toda la brevedad que ser pudiere”. AGS,CMC,1EP,LEG,189, f. 2. 1505, julio, 22. Segovia.

34. En AGS,CMC,1EP,LEG,189, f. 2. 1506, enero, 20. Salamanca: "A ciertos guías traxieron las cosas de la cámara de la rreyna nuestra señora que aya santa gloria desde la çibdad de Segovia a la 


\section{SALAMANCA-VALLADOLID}

La boda de Fernando y Germana de Foix acrecentó los recelos de Felipe de Habsburgo hacia su suegro y abrió un conflicto que afectó al desarrollo de la almoneda. El origen del enfrentamiento estaba en haber nombrado Isabel en su testamento a Fernando gobernador y administrador del reino, en caso de que Juana no quisiere o pudiere entender en la gobernación, en vez de a Felipe, que no soportó verse excluido del gobierno de Castilla. El archiduque envió a sus embajadores para negociar un primer acuerdo con el rey Fernando que se firmó en Salamanca el 24 de noviembre de 1505 -la llamada Concordia de Salamanca-, por la que se establecía un gobierno conjunto entre Juana y Felipe como reyes y Fernando como gobernador perpetuo, pero el Hermoso no se iba a conformar. Apaciguados los ánimos primeros tras esta Concordia, se celebró en la catedral de Salamanca la misa del cabo del año ${ }^{35}$ y se retomó la almoneda. Durante los meses de diciembre y enero se dio un nuevo impulso a las ventas, que supusieron un ingreso de más de dos millones y medio de maravedís. En esta ocasión se aprovechó la presencia de las embajadas de Felipe y Maximiliano de Habsburgo para encontrar nuevos compradores. El rey dio salida a una importante partida de ornamentos confeccionados con las ropas de la reina y el príncipe, lista para distribuirse entre los monasterios e iglesias donde tubo noche el cuerpo de la rreyna nuestra señora que aya santa gloria quando llevaron a Granada, concretamente en las localidades comprendidas entre Toledo y la Alhambra ${ }^{36}$. El rey reservó también una buena cantidad de tejidos para su nieto el infante Fernando ${ }^{37}$. Entregó asimismo una considerable cantidad de dinero a Jorge de Vitoria para recuperar el collar de la reina que seguía empeñado en Valencia, que poco después recibió y cargó a Juan Velázquez ${ }^{38}$.

El rey Fernando partió a Dueñas para encontrarse con su segunda esposa y celebrar allí las velaciones, que se realizaron el 18 de marzo en el palacio de los condes de Buendía. Desde allí se trasladó al día siguiente a Valladolid con toda la Corte con el fin de estar más cerca a la hora de recibir a los reyes de Castilla, Juana y Felipe, que venían de camino. En esta ciudad de nuevo el rey determinó, para completar las donaciones a los lugares por donde había pasado el itinerario del cortejo fúnebre de la reina, que se mandaran siete varas de terciopelo para hacer ornamentos para çiertos monesterios e yglesias donde el cuerpo de su señoría estuvo de noche desde Medina del Campo fasta la çibdad de Toledo ${ }^{39}$. Digno es de reseñar que Germana de Foix, a pesar de estar presente en las subsiguientes sesiones de la almoneda, nunca compró nada de la reina Isabel; no así Juana de

villa de Arévalo y desde la dicha villa de Arévalo a la çibdad de Salamanca çinco mill e quinientos e çincuenta e ocho mrs. por çédula de su altesa fecha en Salamanca a 20 días de henero de IUvi".

35. AGS,CSR,LEG, 8,436 .

36. Documento 10. En AGS,CMC,1EP,LEG,189,3 encontramos los lugares donde fueron destinados los ornamentos enviados desde Salamanca y Valladolid, con sendas datas de 10 de enero y 02 de abril de 1506.

37. AGS,CMC,1EP,LEG,189, f. 6. 1506, febrero, 18. Salamanca.

38. AGS,CMC,1EP,LEG,192, f. 1. 1506, abril, 27. Valladolid.

39. Documento 11. 
Aragón, hija de Fernando el Católico, que destacó por todo lo contrario, al ser una de las mayores compradoras.

Después de desembarcar Juana y Felipe el 26 de abril en la Coruña, tardó todavía el archiduque dos meses en encontrarse con su suegro, tiempo que utilizó para ganarse partidarios de la alta nobleza. Trascurrido este, se presentó en Castilla armado y dispuesto a arrebatar la corona de Castilla aun por la fuerza de la guerra, mas Fernando no estaba en la misma disposición. Al encontrarse el rey de Aragón prácticamente sin apoyos, ni de la nobleza, ni del clero, ni del pueblo, concluyó firmando la Concordia de Villafáfila el 27 de junio de 1506, por la cual renunciaba a la gobernación de los territorios castellanos y se retiraba a su reino de Aragón. El día 10 de julio Felipe entraba triunfante en Valladolid junto a su esposa y dos días después era jurado en las Cortes como rey de Castilla con el nombre de Felipe I. Y, aprovechando que los bienes de la cámara de la reina se encontraban en Valladolid, el nuevo monarca compró para él un breviario rico con muchas iluminaciones y para su hermana Margarita treinta y dos tablas pintadas del llamado políptico de Isabel la Católica que le enviaría a Flandes su camarero Diego Flores ${ }^{40}$. Huyendo de la peste, partió la Corte de esta ciudad y se trasladó a Burgos, caput Castellae. Y al haberse retirado de Castilla el rey Fernando, la almoneda quedó paralizada.

\section{Burgos}

A principios de septiembre los nuevos monarcas establecieron la corte en la ciudad de Burgos. Fueron días de fiestas y torneos que expresaban el triunfo de Felipe I sobre su suegro, sin imaginar nadie que en menos de un mes esta ciudad estaría celebrando los funerales regios del recién estrenado rey, pues murió el 25 de septiembre en la casa del Cordón. Ante tal inesperado acontecimiento, la alta nobleza constituyó un Consejo de Regencia presidido por Cisneros hasta que regresara el rey Fernando, pues con esta muerte, Juana quedaba como única reina de Castilla y su padre el gobernador.

Se cumplían ya casi dos años de la muerte de Isabel y muchos de los objetos estaban todavía sin vender ${ }^{41}$. Quizá por la premura, muchas cosas se habían tasado a precios tan elevados que no encontraron comprador. La orden de una nueva tasación podría dar salida a todos aquellos objetos, pero esta solo podía ser decidida

40. AGS,CMC,1EP,LEG,189, f. 4. Hasta hace poco tiempo se había pensado que las tablas del políptico las compró Diego Flores por encargo de Margarita de Austria, mas el profesor Zalama ha encontrado en la documentación simanquina que la compra la hizo el rey Felipe, quien encargó al camarero de la duquesa de Saboya que se las hiciera llegar. Zalama 2008, p. 61; 2006c, pp. 38-42.47, n.76 (bribiario rico) y 87 (políptico).

41. Hay pliegos y pliegos en uno de los legajos simanquinos en el que las cosas que están por vender de los distintos cargos son interminables AGS,CMC,1EP,LEG,190. 
conjuntamente por los testamentarios, y si no de todos, al menos por el rey con Cisneros $^{42}$, y justo el que faltaba era Fernando.

Después de muchas súplicas para que el monarca se hiciera presente, el 28 de agosto de 1507 llegó a Burgos, donde seguía asentada la Corte, cerca de la reina Juana. Muchas cosas tuvo que despachar al tomar de nuevo las riendas de la corona de Castilla y una de ellas fue, sin duda, la inconclusa almoneda. Emitió una primera cédula en nombre de los testamentarios por la cual se rebajaban los precios de las joyas al quitar a todas ellas el importe de la elaboración o fechura ${ }^{43}$. Suponemos que con el traslado de la Corte desde Valladolid a Burgos, habían venido también los objetos no vendidos allí, a los que se unieron aquellas dieciocho carretas que habían quedado en la casa de Juan Velázquez en Arévalo, como consta en la nómina de pago a çiertos carreteros que truxieron de la villa de Arévalo a esta çibdad de Burgos çiertas cosas de la cámara de la reyna, que alcanzó casi los treinta mil maravedís ${ }^{44}$. Una vez reunido todo en Burgos, mandó por otra cédula real fechada el 2 de diciembre que, aparte de no cobrar en la venta la hechura de las joyas, se ajustara o rebajara el precio, porque muchas de ellas estaban apreçiadas e retasadas en mayores quantías de lo que ellas balen e, a esta causa, se dilata la venta dellas, para lo cual nombró una serie de peritos tasadores para que apreciaran en su justo balor ${ }^{45}$.

Y cuando parecía que el rey ya tenía despachados estos asuntos, se encontró con otra dificultad pecuniaria relacionada con la almoneda que tenía que resolver con urgencia: la altísima dote que había de pagar para que su hija pequeña, Catalina de Aragón, princesa de Gales, se casara con el futuro Enrique VIII ${ }^{46}$. La reina Isabel en su testamento había mandado que se saldaran las dotes acordadas para casar a sus hijas María y Catalina con el rey de Portugal y el futuro monarca de Inglaterra respectivamente ${ }^{47}$. Fernando ya había resuelto los 10.000 ducados de la primera en 1505, la dote de la segunda la había prorrogado. La negociación había sido muy complicada, se había prolongado mucho en el tiempo y había sido ratificada por distintos tratados. El último pacto lo había firmado Felipe el Hermoso el 30 de abril de 1506 con el rey inglés, y en él se había comprometido que en el plazo de dos años se habría completado la entrega de la dote, 65.000 ducados nada menos, sin la cual, no habría boda.

42. AGS,PTR,LEG,30-2, f. 8r. Testamento y Codicilo 2013, p. 35-36.

43. Documento 12.

44. AGS,CMC,1EP,LEG,189, f. 3. 1508, marzo, 29. Burgos. Aquí encontramos un cargo de 29 547,5 mrs. de pago por el traslado desde Arévalo a Burgos: "Más se resçiben e pasan quenta al dicho Juan Velásques veynte e nueue mill quinientos e quarenta e syete maravedís e medio que él dio e pagó a çiertos carreteros que truxieron de la villa de Arévalo a esta çibdad de Burgos çiertas cosas de la cámara de la reyna, nuestra señora, que santa gloria aya, por çédula de su altesa, fecha en la çibdad de Burgos, a XXIX de março de DVIII años". El mismo en AGS,CMC,1EP,LEG,959, s.f.

45. Documento 13. Entre los peritos tasadores, el maestre Felipe, a quien se le encargaron tasar las tablas y libros, se ha demostrado que se trata de Felipe Bigarny. Cf. Martín Barba 2018.

46. Cf. Sevilla 2016.

47. AGS,PTR,LEG,30-2, fol.8r. Testamento y Codicilo 2013, p. 36. 
Fernando se encontró con que este plazo estaba a punto de cumplirse y no tenía liquidez para saldar la dote. Pidió al banquero genovés Agustín de Vivaldo (denominado Agustín Ytalian) que le prestara tal cantidad y que la entregara en Londres, dándole a cambio como aval la corona rica y el collar de balajes que acababa de desempeñar ${ }^{48}$. Fernando acudió a Juan Velázquez para que tomara de la testamentaría de la reina Isabel cuatro cuentos de maravedís y se los entregara al banquero para restituir parte del dinero prestado ${ }^{49}$. Esta cantidad sí la tenía el contador mayor, pero no en numerario sino en especie. Los cuatro cuentos eran el valor de todos los objetos que, tasados, estaban todavía sin vender, por lo que, a partir de este momento, todo el dinero que se obtuviera en la venta de los bienes de la cámara de la reina sería a cuenta del casamiento de la señora prinçesa de Gales $^{50}$, es decir, destinado a saldar la deuda con Agustín Italiano. Contribuyó el rey a la almoneda comprando varios tapices y distintas piezas de oro y plata para su cámara ${ }^{51}$. Se obtuvieron en la venta de Burgos más de seis cuentos de maravedís.

Fernando programó trasladarse a Andalucía con toda la Corte para castigar ejemplarmente las rebeldías del marqués de Priego y el duque de Medinasidonia y mostrar así, como gobernador de Castilla, su autoridad a toda la nobleza. Pero antes pasaría por Valladolid, para presidir la Congregación General de la Inquisición que iba a condenar los abusos del inquisidor Lucero, y por Tordesillas, en cuyo palacio real dejaría a la reina Juana para protegerla así de las posibles revueltas que podrían originar las facciones disconformes con su gobierno. Lo que no esperaba el monarca es que su hija se negaría rotundamente a $i^{52}$. A pesar de los ocho días que pasó Fernando en Arcos de la Llana tratando de convencerla, no consiguió mover en un ápice la voluntad de su hija. Durante estos días los testamentarios aprovecharon para cuadrar con el contador mayor Juan Velázquez los números de la almoneda: por orden del rey entregaron al contador mayor 100.000 maravedís por los desajustes en la contabilidad y le gratificaron con otros 620.000 por los gastos ocasionados en la custodia de toda la hacienda de la reina Isabel en los últimos cuatro años ${ }^{53}$.

48. Documento 14 .

49. AGS,CMC,1EP,LEG,189,4 Cf. Zalama 2005, pp. 339-340. Zalama 2006b, pp. 309-311. A Juan Velázquez en este documento se le piden cuatro cuentos, pero lo que había que pagar de la dote era mucho más. En un cedulario del rey Fernando que abarca los años 1508-09, que se encuentra en la $\mathrm{RAH}$, vemos varios registros de cédulas dirigidos a otras personas que se refieren al pago del préstamo de Agustín Italiano. Cf. Rodríguez Villa (1909).

50. Documento 15. El importe de la dote fue entregado y finalmente Catalina de Aragón se casó con Enrique VIII el 11 de junio de 1509.

51. AGS,CMC,1EP,LEG, 189, fol. 4.

52. Zalama 2010, p. 230.

53. Documento 16 y 17. Poco después, en Valladolid se le pagó también a María Velasco, esposa de Juan Velázquez otros 200.000 maravedís por haberse encargado de las cosas de cámara de la reina: Documento 18 . 


\section{VALLADOLID}

A comienzos de 1509 regresó la corte a Valladolid procedente de Andalucía, y terminadas las fiestas de recibimiento, Fernando se trasladó a Arcos para tomar a su hija Juana y encerrarla, ahora sí, para siempre en el palacio real de Tordesillas ${ }^{54}$. Quedó la Corte establecida en la ciudad del Pisuerga, y allí permaneció hasta enero de 1510. En este período Germana de Foix dio a luz un hijo que murió a las pocas horas $^{55}$. La tristeza se convirtió en gozo en muy poco tiempo cuando llegó a finales de junio de 1509 la noticia del casamiento de Catalina de Aragón con Enrique VIII y su coronación como reyes de Inglaterra, hecho que causó gran contentamiento a Fernando, hasta el punto que no solo mandó celebrar en Valladolid con gran demostración de alegría y con todo aparato y fiesta real, sino que también él mismo ante toda la ciudad jugó a las cañas ${ }^{56}$. Gracias a la almoneda se había conseguido una parte considerable del importe necesario que se tenía que devolver al banquero por el préstamo.

Después de los meses estivales Fernando mandó traer las cosas de la reina Isabel para otra nueva sesión de liquidación con el fin de concluir definitivamente la almoneda ${ }^{57}$. Solo hay una nómina firmada en Valladolid de venta de varias joyas a Juana de Aragón, la hija natural del rey con Aldonza de Ivorra y casada con el condestable Pedro Fernández de Velasco, por importe de ciento cincuenta mil maravedís ${ }^{58}$. Por otra parte, decidió Fernando con los testamentarios que todas las camisas viejas de la reina se enviaran a hospitales ${ }^{59}$, que se hicieran distintos objetos litúrgicos de las ropas de vestir de brocado y seda y paño y otras cosas que heran de su señoría así como varias piezas grandes de distintas telas ${ }^{60}$ para enviar a la Capilla Real de Granada y otras iglesias de dicho reino ${ }^{61}$. Mandó además devolver a Segovia todas las cosas que estaba a cargo de Rodrigo de Tordesillas para las poner en el dicho alcaçar y él las tener a su cargo porque aquellas no son de calidad para que se ayan de vender ${ }^{62}$. Tomó también unas joyas que eran de su hija Juana, encerrada en Tordesillas y que estaban entre las de su esposa, para devolvérselas ${ }^{63}$, y para él mismo compró un portapaz y un ostiario valorados en más de doscientos ochenta mil maravedís ${ }^{64}$.

\footnotetext{
54. Zalama 2010, p. 235-236.

55. Zurita 1580, f. 192v.

56. Zurita 1580, f. 193v.

57. El pago a estos carreteros se hizo dos años después: cf. n. 65 .

58. CMC,1EP,LEG,189,f. 7. 1509, septiembre, 26. Valladolid.

59. CMC,1EP,LEG, 189, fol.11. 1509, octubre, 20. Valladolid.

60. CMC,1EP,LEG, 189, fol.10. 1509, octubre, 22. Valladolid.

61. Documento 19.

62. Documento 20.

63. Documento 21.

64. CMC,1EP,LEG,959. 1509, mayo, 12. Valladolid.
} 


\section{MADRID}

A finales de enero de 1510 el rey y la corte abandonaron Valladolid y tomaron camino de Madrid. En Tordesillas se detuvieron dos días para que Fernando visitara a la reina Juana con el fin entregarle las joyas de su propiedad que estaban entre los bienes de cámara de Isabel; y luego pararon en Arévalo. En esta villa los contadores tomaron declaración jurada a María de Velasco, la mujer de Juan Velázquez, de no haberse quedado con parte de la algalía, porque parece ser que había sido acusada de sisar en este perfume tan $\operatorname{costoso}^{65}$. De los objetos que allí quedaban todavía, el rey tomó algunas cosas para su nieto Fernando, que contaba entonces con seis años y otras para $\mathrm{s}^{\prime 66}, \mathrm{y}$ creemos que debió ser aquí donde tomó la determinación de liquidar la almoneda, al ver en el palacio de Juan Velázquez lo poco que quedaba ya por vender. Dos hechos nos llevan a pensar esto: el primero que el rey mandó que todas las cosas que quedaban de la reina fueron trasladadas a Madrid para sacarlas de nuevo a la venta ${ }^{67}$; el segundo fue la entrega de todos los libros de cuentas de la almoneda a la Contaduría Mayor de Cuentas, organismo encargado de vigilar que hubiera rectitud en las actividades económicas relacionadas con la Corona, para que fueran supervisados por Rodrigo de Coalla y Martín de Mújica ${ }^{68}$, mientras el rey Fernando en Monzón presidía las Cortes Generales de Aragón.

A su regreso al reino de Castilla quiso el rey de nuevo que la almoneda coincidiera con las Cortes, celebradas en Madrid entre el 29 de agosto y el 3 de noviembre, donde los procuradores confirmaron a Fernando como gobernador de Castilla hasta que Carlos llegara a la edad de 20 años, pues muchos de los compradores

65. CMC,1EP,LEG,189,fol.23. 1510, marzo, 17. Arévalo. Cf. Fernández 1981, pp. 104-107.

66. Documento 22 y 23

67. Hay una nómina posterior en la que se paga el uso de las acémilas para el traslado de Arévalo a Valladolid, la subsiguiente devolución a la villa abulense, y posteriormente de esta a Madrid: "Deziseys mile e seysçientos e çinquenta e dos mrs. que se gastaron en bestias de guía en esta manera a quatorze carretas que traxieron las cosas de la cámara dende la villa de Arévalo a la villa de Valladolid seys mile e çiento e setenta. Tres mil e trezientos e diez mrs. a dies carretas que llevaron parte de las dichas cosas de la cámara dende la villa de Valladolid a la villa de Arévalo. Los que los dichos nueve mill e nueveçientos e çiencuenta mrs. dize que se gastaron en presençia del secretario Sebastián de Olano más dos mil seiscientos e çincuenta e dos mrs. a diez açemilas que llevaron las dichas cosas de la dicha camara dende la villa de Arévalo a la villa de Madrid más tres mill e quatrocientos e quarenta e dos mrs. A çiertos azemileros que tornaron las dichas cosas de la cámara dende la villa de Madrid a la villa de Arévalo e çiertos bestidos del príncipe don Juan que santa gloria aya que dice que se llevaron por mandado de su alteza al monesterio de Santo Tomás de Ávila en los quales montaron todos los dichos deziseys mill e seyscientos e çincuenta e dos mrs por çedula de su altesa. Fecha en la çibdad de Sevilla a dieziocho del mes de mayo de quinientos e honze años por la qual se manda se le pasen en quenta los dichos mrs. solamente por virtud de la dicha çédula... XVIUDCLIII". AGS,CMC,1EP,LEG,189, f. 18. 1511, mayo, 18. Sevilla.

68. CMC,1EP,LEG.81, pl. 329: "Conosçemos yo el liçençiado Rodrigo de Coalla e el comendador Martin de Muxica, contadores mayores de cuentas de la Reyna nuestra Señora que resçibimos de vos Martin de Echaue en nombre del secretario Sauastian de Olano en la villa de Madrit a nueue dias del mes de abril de mill e quinientos e diez años, por mandado del Rey nuestro Señor, los libros de la camara de la Reyna nuestra Señora que santa gloria aya en la forma e manera siguientes". 
fueron participantes en las mismas ${ }^{69}$. A principios de 1511 , de lo poco que debía quedar, el rey tomó otras cosas para su cámara ${ }^{70}$.

\section{LOGROÑO}

Fernando el Católico se trasladó a esta ciudad en septiembre para dirigir desde aquí la anexión de Navarra al reino castellano. Una vez que la guerra llegó a su fin, tuvo tiempo para revisar con los contadores las cuentas de Juan Velázquez y firmarle el finiquito en diciembre de 1512, dando así por concluida la almoneda.

Encontramos copia de este documento en los leg. 189 y 959, de la Contaduría Mayor de Cuentas (uno es copia del otro) ${ }^{71}$. En primer término aparece un sumario o suma de las cantidades que Juan Velázquez fue entregando al tesorero real obtenidas de las ventas de los objetos de la reina a lo largo de todo el proceso de la almoneda. Está escrito con numeración romana y sigue el procedimiento de cargo, data y alcance, es decir, ingreso, gasto y diferencia. Este documento, intitulado por la reina Juana y firmado por Fernando como administrador y gobernador, liberaba a Juan Velázquez y a sus descendientes para siempre de cualquier responsabilidad con respecto a los bienes de la reina.

\section{CONCLUSIÓN}

A pesar de que la reina Isabel había fijado un año como plazo para la venta de sus bienes personales, la difícil coyuntura que le tocó vivir al rey Fernando y a sus testamentarios hizo que este proceso se prolongara mucho más de lo previsto. Según la documentación, la venta de los objetos se realizó siempre en el lugar donde se encontraba el rey y dentro del marco de la Corte: consecutivamente primero en Toro (de diciembre 1504 a febrero 1505), Segovia (junio a octubre 1505) y Salamanca (diciembre de 1505) y, tras un largo paréntesis por la retirada del monarca a Nápoles, se retomó la almoneda a su regreso a Castilla en las ciudades de Burgos (entre diciembre de 1507 y abril de 1508), Valladolid (septiembre 1509) y Madrid (enero 1511). Concluyó todo el proceso cuando el rey entregó la carta de finiquito al contador Juan Velázquez de Cuéllar en Logroño en diciembre de 1512.

A la luz de los documentos que se emitieron con motivo de la almoneda, hemos podido aproximarnos a su gestión administrativa ${ }^{72}$. A través de una cédula real refrendada por los albaceas y dirigida a Violante de Albión, Sancho de Paredes y Rodrigo de Tordesillas, el rey expresó su voluntad de que todos los bienes muebles que tuvieran de la reina fueran cargados a Juan Velázquez (documento disposi-

\footnotetext{
69. PTR,LEG,56,DOC.36.

70. Documento 25.

71. Documento 25.

72. Elisa Ruiz describió de manera clara el funcionamiento burocrático, pero solo hasta que fueron recibidos por el contador mayor Juan Velázquez, no indicó nada de la venta. Ruiz 2004, pp. 30-34.
} 
tivo). Al escribano de la cámara, oficial encargado de llevar cuenta de todo lo que entraba y salía de la cámara regia con los libros de inventario y el control del contenido de las arcas numeradas donde se guardaban las cosas de la reina, se le encomendó la dirección de la almoneda, tanto para la tasación de los objetos como para la inspección en el proceso de venta: desde el comienzo esta tarea recayó sobre Suero de Cangas, y a su muerte en enero de 1508, le reemplazó el escribano de la cámara y notario público, Sebastián de Olano ${ }^{73}$.

Otros escribanos también estuvieron presentes en el proceso y produjeron dos tipos de documentos consecutivos. Uno en el que enumeraron todos los objetos traspasados a Juan Velázquez -el leg. 81- con unas escuetas descripciones de cada objeto, copiadas de los libros de cámara de la reina, en el cual se fue anotando, a medida que iba avanzando la almoneda, el nombre del comprador y el valor de tasación y de venta de cada uno. El otro, existen dos copias - los leg. 189 y 959-, en el que los escribanos registraron las nóminas reales emitidas a los compradores en las distintas sesiones de la almoneda, con forma de documento dispositivo, uno por sesión de venta, en el que manda el rey a Juan Velázquez vender las cosas de la reina, y a continuación de lo cual se hace una relación de todas las nóminas de cosas vendidas en forma de cargo y data. En el cargo se recogen cada uno de los objetos, el importe que recibió el contador mayor en maravedís por su venta, los descriptores en el inventario y el nombre del comprador; en la data la fecha y lugar donde fueron entregadas las sumas de estos importes al tesorero real, Francisco de Vargas $^{74}$. Sumando todas las datas obtenemos la cantidad total que se obtuvo en la almoneda: más de diecinueve millones de maravedís (XIX q. LXXXIXU DCCLXIX= 19.089.769 maravedís).

Asimismo, los pagos a los carreteros que trasladaron los objetos desde Arévalo a las distintas sedes donde se vendieron nos han confirmado, por una parte, que el centro de almacenaje de todos los objetos fue el palacio real arevalense, de donde Juan Velázquez era tenente $\mathrm{y}$, por otra, que los traslados fueron costeados por la Corona, bien a través de las arcas reales, bien del mismo numerario obtenido en la almoneda.

\section{ApÉNDiCE DoCUMENTAL}

Presentamos en esta colección los documentos referentes a la almoneda de los bienes de Isabel la Católica que fueron emanados por orden y en nombre del rey Fernando o la reina Juana. Ofrezco la transcripción en el caso de que sean textos inéditos y, si ya han sido publicados, únicamente los menciono y cito sus ediciones.

73. Para enero de 1508 ya había muerto Suero de Cangas, según palabras del mismo rey. Fue entonces cuando le debió de sustituir entonces Sebastián de Olano. Cf. Documento14.

74. Ladero Quesada (2017) pp. 40-41.75. 
1504, diciembre, 14. Toro

Cédula real de Fernando el Católico por la que manda a Violante de Albión, criada de la reina Isabel, que entregue todos los bienes muebles de la Cámara de la reina que tiene a su cargo.

B. AGS,CMC,1EP,LEG,189, pl. 1 s. f.

Ed. Ruiz García 2004, p. 317; Torre 1974, p. 2.

2

1504, diciembre, 24. Toro

Cédula real de Fernando el Católico por la que pide al tesorero Ochoa de Landa que pague al alguacil Cosme de Vallejo el importe del alquiler de las acémilas para el traslado de las cosas de la Cámara de la reina desde Arévalo y Medina del Campo a la ciudad de Toro.

A. AGS,CSR,LEG, 4 , fol. 350

[Arriba centro:] (Cruz)

El rey

Ochoa de Landa. Yo vos mando que de qualesquier maravedís de vuestro cargo dedes y pagades al alguazil Cosme de Vallejo treinta y seys mill nueveçientos e ochenta e çinco maravedís para el alquiler de las asemilas de guía que él hizo traer las cosas de las cámaras de la serenísima rreyna mi muy cara e muy amada muger, que santa gloria aya, de las villas de Medina del Campo e Arévalo a esta çibdat de Toro. E tomad su carta de pago o de quien su poder oviere con la qual e con esta mi çédula tomando la razón della Juan López secretario y qontador mando que vos sea reçibido en quenta los dichos treynta y seys mil nueveçientos ochenta e çinco maravedís y no fagades ende al. Fecho en la çibdat de Toro a veynte e quatro días del mes de diziembre de quinientos y quatro años. Va sobre raydo dos rayas de tinta. Yo el rey (rúbrica).

Por mandado del Rey administrador y governador. Juan López (rúbrica).

1504, diciembre, 30. Toro

Cédula real de Fernando el Católico por la que manda a Sancho de Paredes y su esposa Isabel Cuello, camareros de la reina Isabel, que entreguen todos los bienes muebles de la cámara de la reina que tienen a su cargo.

B. AGS,CMC,1EP,LEG, 189, pl.1 s.f.

Ed. Ruiz García 2004, pp. 318-319; Torre 1974, p. 1-2. 
1505, enero, 27. Toro

Cédula real de Fernando el Católico por la que manda a los contadores mayores que hagan cargo a Juan Velázquez de todas las cosas que recibiere de la cámara de la reina y que le tomen cuenta de todo el dinero que entregare.

B. AGS,CMC,1EP,LEG,189, pl.1 s.f.

Ed. Torre 1974, p. 1-2

[Arriba centro:] (Cruz)

El Rey

Qontadores mayores de cuentas e vuestros lugartenientes. Sabed que por virtud de una cláusula del testamento de la serenýsima reyna, mi muy cara e muy cara (sic) e muy amada muger, que santa gloria aya, yo mandé dar e di dos mis çédulas, firmadas de mi nonbre, fechas en esta guisa:

(se incorporan aquí consecutivamente la cédula para Sancho de Paredes e Isabel Cuello con fecha de 30 de diciembre de 1504 y la dirigida a Violante de Albión del 13 de diciembre)

Por virtud de las quales dichas çédulas suso encorporadas el dicho Juan Velázques reçibió e a de reçebir del dicho Sancho de Paredes e de su muger, e de la dicha Violante de Alvión las cosas quellos tenían de la cámara de la dicha señora reyna, mi muger, que aya santa gloria, para haser dellas lo contenido en las cláusulas del dicho su testamento, encorporada en la una de las dichas dos çédulas de suso insertas, por ende, yo vos mando que cada e quando quel dicho Juan Velázques o otra qualquier o qualesquier personas en su nonbre vos dieren cuenta de las cosas que asý reçibieron de la dicha cámara, se la toméys e reçibáys, haçiéndole cargo de todo lo que paresçiere que le fue entregado y él reçibió de la dicha cámara, e, resçibiéndole en cuenta lo que dio e destribuyó por mandamientos míos e de los dichos testamentarios, con los otros recabdos que vos vierdes que son nesçesarios para la dicha cuenta, e aquella acabada e fenesçida, le dedes al dicho Juan Velázques carta de finiquito en la forma acostunbrada, con que el dicho Juan Velázques e sus herederos queden libres del dicho cargo para syenpre jamás, e no fagades ende al. Fecha en la çibdad de Toro, a XXVII de henero de DV años. Yo, el Rey. Por mandado del Rey, administrador e governador, Gaspar de Grizio.

5

1505, febrero, 15 . Toro

Cédula real de Fernando el Católico por la cual autoriza a Sancho de Paredes a vender los objetos que tiene a su cargo para no alargar la almoneda.

B. AGS,CMC,1EP,LEG, 186

[Arriba centro:] (Cruz)

75. Presento la transcripción de esta cédula real porque en la edición de Antonio de la Torre viene incompleta. 
El Rey.

Sancho de Paredes, camarero de la serenísima reyna, mi muy cara e amada muger, que aya santa gloria. Sabed que yo e los otros testamentarios de su señora acordamos que las joyas de oro e plata e piedras e perlas e brocados e seda e tapiçería e cosas de camas e todas las otras cosas de su cámara se bendan para conplimiento de su ánima, como quier que por una cláusula de las del testamento de su señoría dize que se abýan de entregar todas a Juan Velázquez, la qual dicha cláusula, de berbo ad berbun ( sic), es esta que se sigue:

(Se copia aqui el párrafo del testamento de la reina donde manda vender sus bienes).

E sy todas las dichas joyas de oro e plata e piedras e perlas e otras cosas susodichas el dicho Juan Velázquez oviese de vender, avría mucha dilaçión e no se podría conplir tan presto las mandas qontenidas en su testamento, yo vos mando e doy liçençia e facultad para que vendáys todas las dichas joyas de oro e piedras e perlas e todas las otras cosas de vuestro cargo según que están tasadas en los libros de la cámara de su señora e se tasaren e retasaren agora por ante Suero de Cangas, escrivano de cámara, eçebto los ornamentos e joyas de capilla con que se sirbýa la capilla de su señoría, e los vestidos de su persona, e mando que acudáys con el dinero que montare en las dichas joyas de oro e plata e piedras e perlas e todas las otras cosas que vos tenéys a vuestro cargo, no obstante la dicha cláusula que de suso va encorporada, a Bartolomé de Çuluaga, según que paresçiere estar tasado por los dichos libros, e lo que agora se tasare e retasare, firmado del dicho Suero de Cangas, e, asýmismo, con las çédulas mías, por las quales yo libraré los maravedís que montare en las joyas que yo tomare de las que estovieren a vuestro cargo, e con las obligaçiones de las personas que han tomado fiadas qualesquier cosas de la dicha cámara, para que recabde con ellas los maravedís que en ellas montare, e mando que vos dé conosçimientos de los maravedís que montare en las dichas çédulas e obligaçiones, asý como de los otros maravedís que de vos resçibiere en dineros contados, por quanto las dichas obligaçiones e çédulas se hizieron con acuerdo mío e de los otros testamentarios e por nuestro mandado, e tomar sus cartas $\backslash^{6 v}$ de conosçimientos de todos los maravedís e çédulas e obligaçiones que así le entregáredes, con las quales e con esta mi çédula mando a los contadores mayores de quentas que vos reçiban e pasen en quenta todas las joyas de oro e piedras e perlas e piedras e tapiçería e brocados e sedas e paños e otras cosas que montare en la quenta o quentas de maravedís e çédulas e obligaçiones que asý diéredes y entregáredes al dicho Bartolomé de Çuluaga, e, asýmismo, mando a los dichos contadores que con los conosçimientos quel dicho Bartolomé de Çuluaga vos diere vos descarguen e den por libre e quito de todas las joyas e otras cosas que vos asý vendiéredes, no enbargante quel dicho Bartolomé de Çuluaga lo aya de vos reçibido en dineros e obligaçiones e çédulas, en manera que vos no sea fecho otro cargo alguno de los maravedís que montaron dichas joyas e otras cosas que asý vendiéredes, e mando a los dichos qontadores mayores de quentas e a sus lugarestenientes que no fagan cargo alguno al dicho Juan Velázquez de las cosas susodichas que asý vendiéredes, de quel dicho Bartolomé de Çuluaga vos diere sus conosçimientos, salvo solamente de las cosas que paresçiere que ha resçibido o resçibyere el dicho Juan Velázquez por conosçimientos fyrmados de su nonbre, e por vos pasar en quenta todas las cosas qontenidas en esta dicha çédula no les sea ynputado ni puesto culpa ni cargo a los dichos qontadores mayores de quentas e a sus lugarestenientes. Fecha en la çibdad de Toro, a quinze días del mes de hebrero de mill e quinientos e çinco años. Yo, el Rey. Por mandado del rey, administrador e governador, Gaspar de Grizyo. En las espaldas de la qual dicha çédula estavan escritos los nonbres syguientes: Toletanus. Yspalensis. Antonio de Fonseca. Juan López. 
1505, julio, 4. Segovia

Nómina firmada por Fernando el Católico por la que pide al tesorero Ochoa de Landa que pague a Pedro Patiño el importe del alquiler de las acémilas para el traslado de las cosas de la cámara de la reina desde Toro a las ciudades de Arévalo y Segovia

A. AGS,CSR,LEG,6, fol. 118

[Arriba centro:] (Cruz)

El Rey.

Ochoa de Landa, yo vos mando que de qualesquier maravedís de vuestro cargo dedes e paguedes a Pedro Patiño, teniente de mayordomo que fue de la señora rreyna my muger, que aya santa gloria, treynta mill e seyscientos e ocho maravedís, que él gastó por mi mandado en traer las rrecámaras de su señoría desde la çiudad de Toro fasta Arévalo e a esta çiudad en esta guisa:

- Que dio e pagó martes veynte e nueve de abril deste año de quinientos e çinco años doze mill e dozientos e quarenta marvedís a ocho carretas que partieron desde la dicha çiudad de Toro fasta Arévalo con fazienda del cargo de Sancho de Paredes, por quatro días, a cada carreta a quatro reales, que montan los dichos maravedís: xiiU ccxl.

- Que dio e pagó más viernes seguiente dos días de mayo del dicho año a otras syete carretas que partieron para Arévalo con fazienda del cargo del dicho Paredes: iiiiUdcclx.

- Que dio e pagó más el dicho día a quatro azémilas de guía que se tomaron para llevar la dicha fazienda del cargo del dicho Paredes a Arévalo a las quales se les pagaron por quatro días a rrazón de a cient e diez maravedís cada par dellas por día que montan ochoçientos e ochenta maravedís: Udccclxxx.

- Que dio e pagó más lunes a çinco días del dicho mes otras tres carretas que se partieron para la dicha villa con fazienda del cargo del dicho Paredes al dicho preçio que montan dos mill e quarenta maravedís: iiUxl.

- Que dio e pagó más el dicho día a onze carretas que partieron para Segovia, las syete con la fazienda que estava a cargo de los monteros, e los quatro del cargo de Violante de Alvión, por seys días, a quatro reales por día a cada una, que montan ocho mill e nueveçientos e setenta e seys maravedís: viii U dcccclxxvi.

- Que dio e pagó más a dos de las dichas carretas por que trayan a tres mulas por los dichos seys días diez e ocho reales que son seysçientos e doze maravedís...: Udcxii.

- Que dio e pagó más a çinco azémilas que truxo Violante de Alvión, por quatro días, con un día que estuvieron tomadas antes que se partiesen, a çient e diez maravedis por el par dellas cada día, que montan mill e çient maravedis iUx.

Así que montan los maravedís que así aveys de dar e pagar al dicho Pedro Patiño en la manera que dicha es los dichos treynta myll e seysçientos e ocho maravedís, los quales le dad e pagad en dineros contados e tomad su carta de pago con la qual e con esta mi çédula tomando la razón della el secretaro Iohan López mando que vos sean reçividos en cuenta los dichos treynta mile e seiçientos e ocho maravedís. E non fagades ende al. Fecha en la çiudad de Segovia a quatro días del mes de jullio de quinientos e çinco años.

Yo el Rey.

Por mandado del rey administrador e gobernador, Juan López. 
1505, julio, 22. Segovia

Cédula real de Fernando el Católico a Juan Velázquez para que se vendan las joyas por los precios rebajados por Diego Cano.

B. AGS,CMC,1EP,LEG189, f. 2; AGS,CMC,1EP,LEG178, f. 109

Ed. Torre, 1974: pp. 285-286.

8

1505, agosto, 21. Segovia

Cédula real de Fernando el Católico a Juan Velázquez por la cual manda que las ropas de vestir de la reina se hagan ornamentos para donar a iglesias, monasterio y lugares píos, y que se le quiten del cargo.

B. AGS,CMC,1EP,LEG189, f. 3

[Arriba centro:] (Cruz)

El Rey.

Juan Velasques Contador mayor de la Serenísima rreyna, mi muy cara e muy amada hija e del mi consejo. Yo vos mandé que todas las rropas de vestir asy de brocado e oro tirado e carmesy e de otras sedas e chamelotes que vos aveys resçibido de las cámaras de la serenísima rreyna mi muy cara e muy amada muger que aya santa gloria asy de Sancho de Paredes como de Biolante de Alvión las fagades todas faser ornamentos para las dar a yglesias e monesterios e lugares píos donde yo e los otros testamentarios de su señoría viesemos que conviene e mando a Suero de Cangas escribano de la cámara que por virtud de esta mi çédula syendo presente al cortar de las dichas ropas vos las descargue del cargo donde vos las tiene cargadas e a los contadores mayores de cuentas que solamente con su fe de tomólas dichas ropas se han fechos ornamentos syn otro recabdo ni diligençia alguna vos las reçiban e pasen en cuenta e solamente vos fagan cargo de los dichos ornamentos que de las dichas ropas se hisieren e no fagades ende al. Fecha en Segovia a veynte e un días de agosto de mill e quinientos e çinco años. Yo el rrey. Firmado del rey administrador e governador. Juan López. Toletanus. Juan López (sic).

1505, septiembre, 03. Segovia

Cédula real de Fernando el Católico a Juan Velázquez por la cual manda que con las ropas de vestir del difunto príncipe Juan, que estaban en la cámara de la reina, también se hagan ornamentos para dar en limosna a iglesias, monasterio y lugares píos, y que se le quiten del cargo

B. AGS,CMC,1EP,LEG,189, f. 2.

[Arriba centro:] (Cruz) 
El Rey.

Juan Velasques Contador mayor de la Serenísima rreyna, mi muy cara e muy amada hija e del mi consejo. Ya sabeys como yo con acuerdo de los otros testamentarios de la rreyna mi muy cara e muy amada muger que aya santa gloria vos enbié a mandar por una my çedula firmada de mi nombre que todas las ropas de sedas e brocados que fuesen de su señoría las fisiesedes ornamentos para dar en limosna a yglesias e monesterios a porque demás de las dichas rropas ay en la cámara algunas rropas que fueron del prínçipe don Juan mi hijo que santa gloria aya, e guarniçiones e paños de andas de seda e brocado e otros pedaços que fueron de su señoría e de dicho prínçipe mi hijo que han servido e pueden aprovechar para los dichos ornamentos, por ende yo vos mando que todo lo que desta calidad teneys en vuestro poder gasteis en los dichos ornamentos e asymismo que de los lienços de olanda e naval e bretona e inglos e birretes e bocacanes que tenys en vuestro poder hagays hasta alvas e guarniçiones e todos los otros aparejos nesçesarios para los dichos ornamentos. E mando a Suero de Cangas escribano de la camara que por virtud desta mi çédula vos los descargue del cargo donde vos los tiene cargados cortando los dichos brocados e sedas e lienços en su presençia e a los contadores mayores de cuentas en con fe del dicho Suero de Cangas vos los resçiban e pasen en cuenta syn vos pedir ni demandar otro recabdo ni deligençia alguna e no fagades ende al. Fecha en la çibdad de Segovia a tres días de setiembre de mile e quinientos e çinco años. Yo el rrey. Firmado del rrey administrador e gobernador. Juan Lopes. Toletanus, Juan Lopes (sic).

1506, enero, 14. Salamanca

Mandato para que Ochoa de Landa pague a Pedro Patiño tres mil mrs. para el alquiler de las acémilas que llevarán los ornamentos a las iglesias donde pasó la noche el cuerpo de la reina, desde Toledo hasta Granada.

A. AGS,CSR,LEG, 8,439

Ochoa de Landa, de qualesquier mrs. de vuestro cargo dad e pagad a Pedro Patiño tresmill mrs. para alquiler de las azemilas que lleva a Granada con los hornamentos que su altesa e los señores testamentarios mandaron que lleve e desde Toledo adelante. Ha de ir por los lugares donde tubo noche el cuerpo de la rreyna nuestra señora que aya santa gloria quando llevaron a Granada por que ha de dar çiertos hornamentos en las yglesias y monesterios donde tuvo noche el cuerpo de su altesa e tomad su carta de pago con la qual e con la çédula de su altesa para ello teneys vos serán reçibidos en cuenta los dichos tres mill mrs. e si mas saneamiento ovieres menester yo quede de vos dar. Fecha en Salamanca a quatorze días del mes de henero de quinietos e seys años. Juan López.

1506, abril, 02. Valladolid

Cédula real de Fernando el Católico a Juan Velázquez para que de las sedas a su cargo se hagan cenefas para ornamentos destinados a los lugares píos por donde pasó el cuerpo sin vida de la reina.

B. AGS,CMC,1EP,LEG,189, f. 9. 


\section{[Arriba centro:] (Cruz)}

El Rey.

Ioan Velasques nuestro contador mayor e del consejo. Yo vos mando que de las sedas de vuestro cargo que reçibistes de las cámaras de la señora reyna mi muy cara e muy amada muger que aya santa gloria dedes a Ochoa de Landa syete varas de terciopelo carmesí para çenefas que se havrán de faser para çiertos fornamentos que yo e los otros testamentarios de su señoría acordamos de mandar a çiertos monesterios e yglesias donde el cuerpo de su señoría estuvo de noche desde Medina del Campo fasta la çibdad de Toledo e tomad su carta de pago con la cual e con esta mando que vos sean reçibidos en quenta las dichas syete vara de terciopelo carmesí. E no fagades ende al. Fecha en la villa de Valladolid a doss días del mes de abril de quinientos seys años. Yo el rrey por mandado de su alteza. Juan López. Arçobispo. Juan López.

1507, septiembre, 19. Burgos

Cédula real de Fernando el Católico a Juan Velázquez, contador mayor, para que se abarate el precio de los objetos quitando el valor de las "fechuras" con el fin de no dilatar la almoneda.

B. AGS,CMC,1EP,LEG,189,4; AGS,CMC,1EP,LEG,959; AGS,CCA,CED,19,f.131.

[Arriba izquierda:] Çédula que no se carguen las hechuras de las cosas de oro y plata. [Arriba centro:] (Cruz).

El Rey.

Juan Velásques, contador mayor e del consejo de la serenísima reyna, mi muy cara e muy amada hija. Ya sabéys como están en vuestro poder çiertas joyas de oro e de plata e otras cosas que quedaron en las cámaras de la señora reyna, mi muy cara e muy amada hija (sic), que santa gloria aya, que recibistes de Sancho de Paredes, camarero, e Biolante de Albión, de Diego Cano e de Rodrigo de Tordesillas, de los que estavan en el Alcaçar de Segovia, e de otras personas, los quales se vos entregaron por virtud de una cláusula del testamento de su señoría, de las quales joyas e oro e de plata e otras cosas que estavan apreçiadas, las hechuras de los libros de las cámaras de su señoría, e, al tienpo que se vos entregaron, vos fue fecho cargo de las dichas fechuras juntamente con el balor de las dichas joyas e cosas, segúnd estavan apreçiadas en los dichos libros, e las cosas que no estavan apreçiadas se apreçiaron de nuevo con las dichas fechuras, e por quanto yo, el reberendísimo cardenal de España, e los otros testamentarios de su señoría somos ynformados que si las ventas de las dichas joyas de oro e de plata se oviesen de haser con las dichas echuras abría dilaçión e al cumplimiento del testamento de su señoría conbiene toda brevedad que ser pudiere, avemos acordado que las dichas joyas de oro e de plata e otras cosas que así reçibistes de las cámaras de su señoría se devan por los preçios que estuvieren estimados e tasados en el dicho vuestro cargo, sin preçio alguno de las dichas echuras, que así fueron tasados (sic) e después moderadas, mandamos a los qontadores mayores de cuentas que, de las dichas cosas de vuestro cargo que bendierdes de aquí adelante, vos reciban e pasen en quenta todo lo que vos estuviere cargado sin las dichas echuras e vos fagan cargo solamente por ellas de los maravedís en que estubieren tasados, syn preçio de las dichas echuras, e mando al secretario Sebastián de Olano, que tiene por mi mandado los libros de las dichas cámaras, 
que en el cargo que vos está fecho de las dichas joyas de oro e de plata e otras cosas, asiente el treslado desta çédula en los dichos libros e, por virtud della, os aga cargo de las dichas $/ /{ }^{1 v}$ cosas, cargando a vos los preçios en que están tasadas syn las dichas echuras, e no más ni allende, e no fagades ni fagan ende al. Fecha en la çibdad de Burgos, xix días del mes de setienbre de IU DVII años. Yo, el Rey. Por mandado de su alteza, Lope de Conchillos. Cardenalis. Antonio de Fonseca, concertador (rúbrica).

13

1507, diciembre, 02. Burgos

Cédula real de Fernando el Católico a Juan Velázquez, contador mayor, para que todos los objetos de la cámara de la reina que no hayan sido vendidos, se tasen de nuevo en su justo valor.

B. AGS,CMC,1EP,LEG,189,4

\section{[Arriba centro:] (Cruz)}

El Rey.

Juan Belásquez, qontador mayor e del consejo de la serenísyma reyna, mi muy cara e muy amada hija. Ya sabéys como por una mi çédula firmada de mi nombre, dada con acuerdo del reberendísimo cardenal de España e de los otros testamentarios de la señora reyna, mi muy cara e muy amada muger, que santa gloria aya, vos está mandado que todas las joyas de oro e de plata que son a vuestro cargo de las cámaras de su señoría se vendan por los preçios que están tasados e después moderadas por los libros del camarero de su señoría, syn preçio alguno de fechuras, por que más preçio se puedan bender para cunplir las mandas e cosas en su testamento qontenidas, e porque somos ynformados que muchas de las dichas joyas están tasadas juntamente con las dichas fechuras, por manera que no puede bien saber la quantidad que balen las dichas echuras e, asimismo, somos ynformados que muchas de las dichas joyas e oro e plata e piedras e perlas e aljófar e tapiçería e otras cosas del dicho vuestro cargo están apreçiadas e retasadas en mayores quantías de lo que ellos balen e, a esta causa, se dilata la venta dellas, e porque para cunplir las mandas e cargos del testamento de su señoría conbiene que las dichas joyas e tapiçería e las otras cosas de vuestro cargo se vendan e no se dilate la venta dellas, avemos acordado que las dichas joyas de oro e plata e piedras e perlas e tapiçería e las otras cosas del dicho vuestro cargo se tasen e apreçien en su justo balor en esta manera: las dichas joyas de oro e plata e piedras e perlas e aljófar e las otras cosas de oro e plata por Pedro Fernándes e Diego de Ayala, plateros que primeramente entendieron en la tasa $/ / 2 \mathrm{r} \mathrm{e}$ apreçios de las cosas de la cámara, e la tapiçería e sedas e brocados e paños por Pedro de Covarrúvias e Juan de la $<$ Mota $>$, e las pinturas e tablas e libros por maese Felipe, e la ropa e lienços e camas e zarzaanes e guadameçís e las otras cosas por Gajardo, que, asimismo, entendió en los apreçios de las dichas camas e, asimismo, tasen e apreçien los dichos Diego de Ayala e Pedro Fernándes, plateros, las fechuras de las dichas joyas e oro e plata por sí, porque mejor le esté para la quantidad delas, los quales dichos apreçios e tasa de la sobredichas cosas se hagan por los dichos Pedro Fernándes e Diego de Ayala e Gajardo e maese Felipe e Pedro Covarruvias e Juan de la Mota por los preçios justos e razonables que buenamente balieren, que se puedan bender con juramento que primeramente hagan que la dicha tasa e apreçios se harán con toda fidelidad que en ello no abrán fraude ni engaño, por $^{76}$ ende yo vos

76. Tachado: $\mathrm{m}$. 
mando que vendáys las dichas joyas e tapiçería e las otras cosas que así son a vuestro cargo por los preçios e segúnd que por los dichos Diego de Ayala e Pedro Hernándes, plateros, e Pedro de Covarruvias e Juan de la Mota e Gajardo e maese Felipe fuere tasado e apreçiado, e mando a los qontadores mayores de quentas que las sobredichas cosas del dicho vuestro cargo que de aquí adelante dierdes, vos reçiban e pasen en quenta e fagan cargo pro la tasa e apreçios que los sobredichos fizieren, e mando al secretario Sebastián de Olano, que por mi mandado tiene los libros de las dichas cámaras, que en el cargo que vos está fecho de las dichas cosas e joyas, asiente el treslado desta çédula e, por virtud della, vos fagan cargo de las dichas cosas, cargándovos los preçios que los sobredichos Pedro Fernándes e Diego de Ayala e maese Felipe e Gajardo e Pedro de Covarruvias e Juan de la Mota tasaren e no por los preçios que hasta aquí estavan tasados e están asentados en los dichos libros, sacando todabía la quantydad de las dichas fechuras, e no fagades ni fagan ende al. Fecha en la çibdad de Burgos, II de diçienbre de DVII años. Yo, el Rey. Por mandado de su altesa, Lope Conchillos. Conçertada con el original (rúbrica).

(a continuación del pliego viene el doc. 9)

14

1508, enero, 3. Burgos

Cédula real de Fernando el Católico a Juan Velázquez, contador mayor, para que Jorge de Vitoria entregue la corona y el collar de balajes a Agustín de Vivaldo como aval del préstamo.

B. AGS,CMC,1EP,LEG, 189,4.

Ed. Torre, 1974: pp. 286-288.

1508, enero, 03. Burgos

Cédula real de Fernando el Católico dirigida a Juan Velázquez, contador mayor, para que todo el dinero que obtenga con la almoneda hasta tres millones (cuentos) de mrs. se los entregue a Agustín Italiano (Vivaldo) a cuenta de la dote de su hija Catalina de Aragón, princesa de Gales.

B. AGS,CMC,1EP,LEG, 189,4

[Arriba centro:] (Cruz)

El Rey.

Juan Velásques, qontador mayor e del qonsejo de la serenísima reyna mi muy cara e muy amada hija. Bien sabéys como para cumplir el casamiento de la serenísima prinçesa de Gales, mi muy cara e muy amada hija, se an de cumplir de la cámara que vos tenéys a vuestro cargo IIII quentos de maravedís, de los quales avéys de pagar luego los III quentos dellos, y por quanto Agustín Ytaliano está obligado a pagar lxvU ducados en Londres para el dicho casamiento e a de aver los dichos III quentos de maravedís, por ende yo vos mando que luego déys e paguéys al dicho Agustín Ytaliano los dichos tres cuentos de maravedís en dineros, lo que tubierdes de lo que se a bendido de la dicha cámara, e lo restante para cumplimiento en plata e oro de lo que tenéys de la dicha cámara, dándole las cosas que fueren de oro e de plata puramente se a de dar por el peso e ley que tubiere, e las cosas que 
fueren de plata e doradas se an de dar la plata por lo que pesare y el oro segúnd fue tasado, syn que se cuente ninguna cosa por las echuras, e tomad su carta de pago o de quien su poder oviere, con la qual e con esta mi çédula mando que vos sea resçibido en quenta e, a mayor abundamiento, vos prometo e doy mi fee e palabra real de vos mandar dar nómina bastante para vuestro saneamiento e descargo, firmada de mi nonbre e señalada de los testamentarios, por la qual se vos pase e reçiba en quenta todo lo que así dierdes e pagardes al dicho Agustín Ytaliano, e vos reliebo de qualquier cargo o culpa que por lo susodicho os pueda ser ynputado. Fecha en la çibdad de Burgos, tres de enero de mill e quinientos e ocho años. Yo, el Rey. Por mandado de su alteza, Juan Lópes. Cardenal. Antonio de Fonseca. Juan Lópes (rúbrica).

[Al margen izquierdo:] Concertada con la original.

1508, julio, 06. Burgos

Cédula real de Fernando el Católico dirigida a los contadores mayores de cuentas para que entreguen a Juan Velázquez cien mil mrs. por el desajuste entre los aprecios anotados en los libros y el precio real de venta de los mismos.

B. AGS,CMC,1EP,LEG,189,15

[Arriba izquierda:] El dicho Juan Velásques. Data para que le reçiban en cuenta por las cosas que perdió en las cosas de la cámara. CU.

[Al marguen derecho:] CU. Pasanse en quenta en un partido de DCCXxU al pie de los VIII pliegos que luego fise.

[Arriba centro:] (Cruz)

El Rey.

Por quanto por mí e por el reverendísymo cardenal de España fue visto i sabido, por fe de los escrivanos de la cámara de la señora reyna doña Ysavel, $<$ mi muger $>$, que santa gloria aya, que todas las cosas que Juan Velásques, qontador mayor, ha fecho vender de la cámara de la señora reyna, demás de lo que estavan tasadas, se ha cargado en su cuenta a cómo se vendieron e no cómo estavan tasadas, por donde paresçe que para las pérdidas él no ha resçebido ningúnd ynterese, e porque no es rasón que las aya de pagar, por ende, por la presente, mando a vos, los qontadores mayores de cuentas, que resçibáys e paséys en cuenta por pagamientos al dicho Juan Velásques en la cuenta que os da de las cosas de la dicha cámara para las dichas pérdidas ${ }^{77}$, por virtud desta mi çédula, cient mill maravedís syn le pedir otros recabdos algunos, con que el dicho Juan Velásques, por otra parte, no dé ni cuente pérdidas de ninguna cosa de las de la cámara sy no que él las aya de pagar, e no fagades ende al. Fecha en la çibdad de Burgos, a vi días del mes de julio de quinientos e ocho años. Yo, el Rey. Por mandado de su altesa, Lope Conchillos. Cardenalis (rúbrica).

77. Tachado: cient. 
1508, julio, 15. Arcos

Cédula real de Fernando el Católico dirigida a Juan Velázquez para que tome para sí seiscientos veinte mil mrs. de lo obtenido en la almoneda como gratificación por los gastos producidos en el mantenimiento de los objetos de la cámara de la reina en su casa en los últimos cuatro años.

B. AGS,CMC,1EP,LEG,189,15

\section{[Al margen derecho:] DCXX U.}

[Arriba centro:] (Cruz)

El Rey.

Por quanto por mí e por el reverendísymo cardenal de España fue visto que Juan Velásques, contador mayor, ha gastado en tener la hasyenda de la señora reyna, mi muger, que santa gloria aya, los años pasados de quinientos e çinco e quinientos e seys e quinientos e syete y este presente año de DVIII, seysçientas (sic) y veynte mill maravedís en cosas quél gastó con la hasyenda, de que es mi merçed e mando que no le sea pedida otra cuenta ni recabdamiento alguno, por ende, por la presente, mando al dicho Juan Velásques que de los maravedís que se ha avido [al margen: $\mathrm{i}$ di, como la de antes désta] ${ }^{78} \mathrm{o}$ oviere de la hasyenda de la dicha señora reyna, tome e se encargue, de las dichas seysçientas (sic) e e veynte mill maravedís, que es mi merçed i mando que aya e lleve por lo susodicho, que por sola esta mi carta, syn otro recabdo alguno, mando a los qontadores mayores de cuentas o otras qualesquier personas que tomaren sus cuentas, que le resçiban e pasen en cuenta las dichas seysçientas (sic) veynte mill maravedís. Fecha en Arcos, a Xv días del mes de julio de mill e quinientos e ocho años. Yo, el Rey. Por mandado de su altesa, Lope Conchillos. Cardenalis (rúbrica).

1509, mayo, 01. Valladolid

Cédula real de Fernando el Católico dirigida a los contadores mayores para que libren a María de Velasco, esposa de Juan Velázquez, doscientos mil mrs. por el tiempo que se ha encargado de las cosas de la cámara de la reina.

B. CCA,CED, 7,184,4

\section{[Arriba centro:] (Cruz)}

El Rey.

Contadores Mayores. Yo vos mando que los xLU que la serenísima rreyna mi muger que santa gloria aya mandaba librar en cada un año a doña María de Velasco, muger de Juan Belazquez e le están por librar de los años pasados de DV, DVI, DVII, DVIII que son cuatro años que los libreys por que estos dichos años ha entendido en las cosas de la cámara de su señoría e libradgelos en qualesquier rentas destos reynos de qualesquier años pasados, o deste presente año de la fecha desta çédula, o de los años venideros donde le sean çiertos e bien pagados. Dellos le dad e librad desde luego las cartas de libramiento e otras provisio-

78. Tachado: dado. 
nes que menester ovyere e non fagades ende al. Fecha en Valladolid a 1 de mayo de DIX. Yo el rrey. S. Çapata.

1509, octubre, 29. Valladolid

Cédula real de Fernando el Católico dirigida a Juan Velázquez para que, con todos los trajes y vestidos de Isabel y del principe don Juan que se encontraban en las cámaras de la reina, se hagan ornamentos litúrgicos para las iglesias y monasterios, autorizando a comprar lo que fuera necesario para la confección.

B. AGS,CMC,1EP,LEG189, f. 20

\section{[Arriba centro:] (Cruz)}

El Rey.

Juan Velasques contador mayor y del consejo de la serenísima rreyna mi muy cara e muy amada hija. Yo vos mando que todas las ropas de vestir así de brocado e seda e chamelotes e paños de grana e otros colores que vos aveys reçibido de las dichas camaras de la señora rreyna mi muger que aya santa gloria de sus vestidos e del príncipe don Juan nuestro hijo así de Sancho de Paredes e de Violante de Alvión e de otras personas las fagades todas faser hornamentos para los dar a las yglesias e monasterios e lugares píos donde yo e los otros testamentarios de su señoría vieremos que conbiene e si algunos brocados e sedas e çenefas fueren menester e neçesarios para los dichos hornamentos los fagades dar e mando al secretario Sebastián de Olano que por mi mandado entiende en las ventas de las dichas cosas de las dichas cámaras que por vertud desta mi çédula syendo presente al cortar de las dichas ropas e brocados e sedas e otras cosas vos las descarguen del cargo donde vos están cargadas y a los contadores mayores de cuentas que solamente con su fee de como las dichas ropas e brocados e sedas e çenefas e cordones e chamelotes e otras cosas de la dicha camara se han cortado y echo hornamentos y dando por vos para ello que sin otro recabdo ni diliegençia alguna vos las rreçiban en cuenta y solamente vos fagan cargo de los dichos fornamentos e asimesmo vos mando que para las alvas e otras cosas que sean neçesarias para los dichos hornamentos fagays conprar los lienços de Nava y Bretaña y de otra calidad que fuesen neçesarias e la cantidad de más porque se conprare mando a los dichos contadores mayores de cuentas que pareçiendo por fee del dicho Sebastián de Olano de como se conpraron e cortaron e gastaron para las dichas alvas e otras cosas neçesarias para los dichos hornamentos vos los reçiban e pasen a cuenta de los mrs. que son vendidas las joyas de oro e plata y otras cosas de las dichas cámaras. Fecha en la villa de Valladolid a veyte e nueve días del mes de otubre de quinientos e nueve años. Yo el rrey. Por mandado de su alteza, Sebastián de Olano.

1510, enero, 26. Valladolid

Cédula real de Fernando el Católico dirigida a los contadores mayores de cuentas para que se devuelvan al alcázar de Segovia todas las cosas que habian quedado sin vender y que se descarguen a Juan Velázquez.

B. AGS,CMC,1EP,LEG,189, f. 12. 


\section{[Arriba centro:] (Cruz)}

El Rey.

Contadores mayores de quentas. Sabed que yo con acuerdo de los testamentarios de la señora reyna mi muger que aya santa gloria acordamos que algunas cosas de las que entregó Rodrigo de Tordesillas vezino de la çibdad de Segovia a Juan Velázquez contador mayor del consejo, que estavan en el alcaçar de la dicha çibdad que hera a su cargo, las tornase a dar y entregar al dicho Rodrigo de Todesyllas para las poner en el dicho alcaçar y él las tener a su cargo porque aquellas no son de calidad para que se ayan de vender las quales dichas cosas que asy se le entregaron son las que adelante sean nombradas e declaradas en la forma e manera syguiente:

(22 pliegos).

Porque vos mando que reçibays e paseys en quenta al dicho Juan Velázquez todo lo contenido en esta nomina con carta de pago del dicho Rodrigo de Tordesillas de como de lo que rreçibió syn otro rrecabdos algunos e hagays cargo de todo ello al dicho Rodrigo de Tordesillas e ansy mismo mando al secretario Sebastián de Olano que por mi mandado tiene los libros de las cámaras de la señora rreyna mi muger que santa gloria aya e entiende en las dichas cosas que en los logares donde les están cargados las sobredichas cosas le descargue al dicho Juan Velásquez e non fagades ende al. Dada en la villa de Valladolid a xxvi días del mes de henero año de quinientos e diez años. Yo el rrey. Por mandado de su alteza Miguel Pérez de Almaçan.

1510, enero, 25. Valladolid

Cédula real de Fernando el Católico dirigida a Juan Velázquez, contador mayor, para que devuelva distintos objetos de la reina Juana a Diego de Ribera, su camarero.

B. AGS,CMC,1EP,LEG,189, f. 14

[Arriba centro:] (Cruz)

El Rey.

Juan Velasquez contador mayor e del consejo de la serenisima rreyna mi muy cara e muy amada hija. Ya sabeys como la señora rreyna mi muy cara e muy amada muger que santa gloria aya dexó mandado por su testamento que todas las cosas que la dicha serenisima rreyna mi hija dio a su señoría se le bolviese e no se vendiese con las otras cosas de sus camaras para el descargo de su anima por ende yo vos mando que deys y entregueys a Diego de Ribera camarero de la dicha rreyna mi fija las cosas que de yuso e en esta nomina serán contenidas que pareçe que fueron suyas e se las entregaron para las al dicho camarero tenga en la camara en uno con las otras cosas de su cargo.

(una cadena de oro, un rosario de oro, una copa de cristal...)

Así dadas y entregadas las dichas cosas en esta nomina suso que es tomad carta de pago dellas del dicho Diego de Ribera camarero con la qual e con esta mando a los qontadores de cuentas que vos las reçiban e pasen a cuenta sin otro recabdo e no fagades ende al. Fecha en la villa de Valladolid a veinte e çinco dias del mes de henero de mile e quinietos e dies años. Yo el rrey por mandado de su altesa. Miguel Peres de Almaçan. 
1510, febrero, 04. Arévalo

Cédula real de Fernando el Católico dirigida a Juan Velázquez para que entreguen a Sancho de Paredes, camarero del infante Fernando, una serie de objetos de la cámara de la reina para su nieto, y le sean descargados al contador mayor.

B. AGS,CMC,1EP,LEG, 189, f. 23

[Arriba centro:] (Cruz)

El Rey.

Juan Velazquez contador mayor e del consejo de la serenísima rreyna mi muy cara e muy amada hija. Yo vos mando que de las cossas de la cámara de la señora rreyna mi muger que aya santa gloria deys para el ynfante don Fernando mi nieto a Sancho de Paredes su camarero las cosas siguientes:

(unas coraças de brocado rraso blanco guarnesçidas e vordadas de carmesí e hilo de oro, más coraças, yelmos, un escudo de madera, arneses, texillos, arca, silla de mula, otras sillas, una veleta, un alba de lienço de Flandes...)

Así dadas e entregadas las dichas cosas al dicho Sancho de Paredes reçibíd su carta de pago de como las reçibe de vos con la qual e con esta mando a los contadores mayores de quentas que vos las reçiban e pasen a cuente sin otro recabdo alguno a tal secretario Sebastián de Olano que entiende por mi mandado en las cossas de la cámara e las descarguen en el libro que él tiene donde vos están cargadas fechan en Arévalo a quatro días del mes de hebrero de quinientos e diez años. Yo el Rey. Por mandado de su alteza Miguel Pérez de Almaçan.

1510, septiembre, 30. Madrid

Cédula real de Fernando el Católico dirigida a Juan Velázquez por la que compra para su cámara una serie de objetos de la cámara de la reina su esposa.

B. AGS,CMC,1EP,LEG,189, f. 13

\section{[Arriba centro:] (Cruz)}

El Rey.

Juan Velasques contador mayor del consejo de la serenisima reyna mi muy cara e muy amada hija. Ya sabéys como yo y el reverendísimo cardenal d'España e los otros testamentarios de la señora reyna mi muger que santa gloria aya avemos acordado que todas las joyas de oro y plata e otras cosas que son a vuestro cargo de la cámara de su señoría están para el casamiento de la ylustrísisma prinçesa de Galis que agora es reyna de Ynglaterra mi muy cara e muy amada hija que de más e allende de otros çiertos maravedís que aveys dado e pagado a otras personas por otras mis nominas e para el dicho casamiento segund más largamente en las dichas nominas se conviene deys e pagueys al liçençiado Françisco de Vargas tesorero e del Consejo dozientas e noventa mill mrs. seteçientos e ocho mrs. para en cuenta del dicho casamiento las cuales son de çiertas cosas de oro en esta mi nomina quenta que se vendieron para mi camara que montan las dichas dozientas y noventa mile y seteçientos y ocho mrs. son las siguientes e en esta manera: 
(una tabla con la imagen de nuestra señora con su hijo en los brazos con dos ángeles y en la otra tabla una ystoria cuando abaxaron a nuestro señor de la cruz, una imagen de oro de nuestra señora puesta sobre un pie prolongado sobre cuatro almoadas esmaltadas, una sortija de oro, un portapaz de oro)

Así que montan los mrs. porque se vendieron las dichas cosas de oro dozientas y noventa mile y nuebeçientos e ocho mrs. con los quales vos mando que acudades al dicho liçenciado Francisco de Vargas tesorero e tomad su carta de pago con la qual e con esta mi nomina mando a los contadores mayores de cuentas que vos las reçiban e pasen en cuenta sin vos pedir ni demandar otro recabdo alguno e no fagades ende al. Fecha en la villa de madrid a treinta dias del mes de setiembre de mile e quinietos e dies años. Yo el rrey por mandado de su altesa. Miguel Peres de Almaçan.

1511, enero, 04. Madrid

Cédula real de Fernando el Católico dirigida a Juan Velázquez por la que toma -no compra-para su cámara una serie de objetos de la cámara de la reina su esposa: la Siete Partidas, un reloj, tres libros más ${ }^{79}$ y unos cuadernos iluminados.

B. AGS,CMC,1EP,LEG,189, f. 22

\section{[Arriba centro:] (Cruz)}

El Rey.

Juan Velázquez contador mayor e del Consejo de la serenísima reyna mi muy cara e muy amada hija. Vien sabeys como la señora reyna mi muy cara e muy amada muger que santa gloria aya mandó por una claúsula de su testamento que de las joyas e cossas de que yo me quisiese servir de su cámara me sirviese segúnd más largamente. En la dicha claúsula se contiene la qual está encorporada en otras nóminas e çedulas que yo he mandado dar para vos e agora sabed que mi voluntad es de tomar por virtud de la dicha claúsula de las cosas que están en vuestro poder que fueron de la dicha cámara de su señoría las cosas seguientes:

[libro en pergamino de mano con las Siete Partidas, un reloj, tres libros más y unos cuadernos iluminados]

Por ende yo vos mando que las dedes e entreguedes al comendador Juan Cabrero mi camarero e tomad su carta de conosçimiento de como las resçibe de vos con la qual carta e esta mando a los contadores mayores de cuentas que vos las reçiban e pasen en cuenta syn vos pedir ni demandar otro recabdo alguno e no fagades ende al. Fecha en la villa de Madrid a quatro días del mes de henero de quinientos e onze años. Yo el rrey por mandado de su alteza Miguel Pérez de Almaçan.

79. Estos tres libros están descritos así: La dotación del monasterio de Santiago de la ciudad de Granada, [...] otro libro donde están copiadas las bulas y todo lo que se fizo en los patronazgos de los obipados y benefiçios de Granada y [...] otro libro escripto en pergamino de mano de marca mayor que diz ores de Antonio Corseto. 
1512, diciembre, s.d. Logroño

Fernando el Católico extiende a Juan Velázquez la carta de finiquito B. AGS,CMC,1EP,LEG,189, f. 25; AGS,CMC,1EP,LEG,959, s.f.

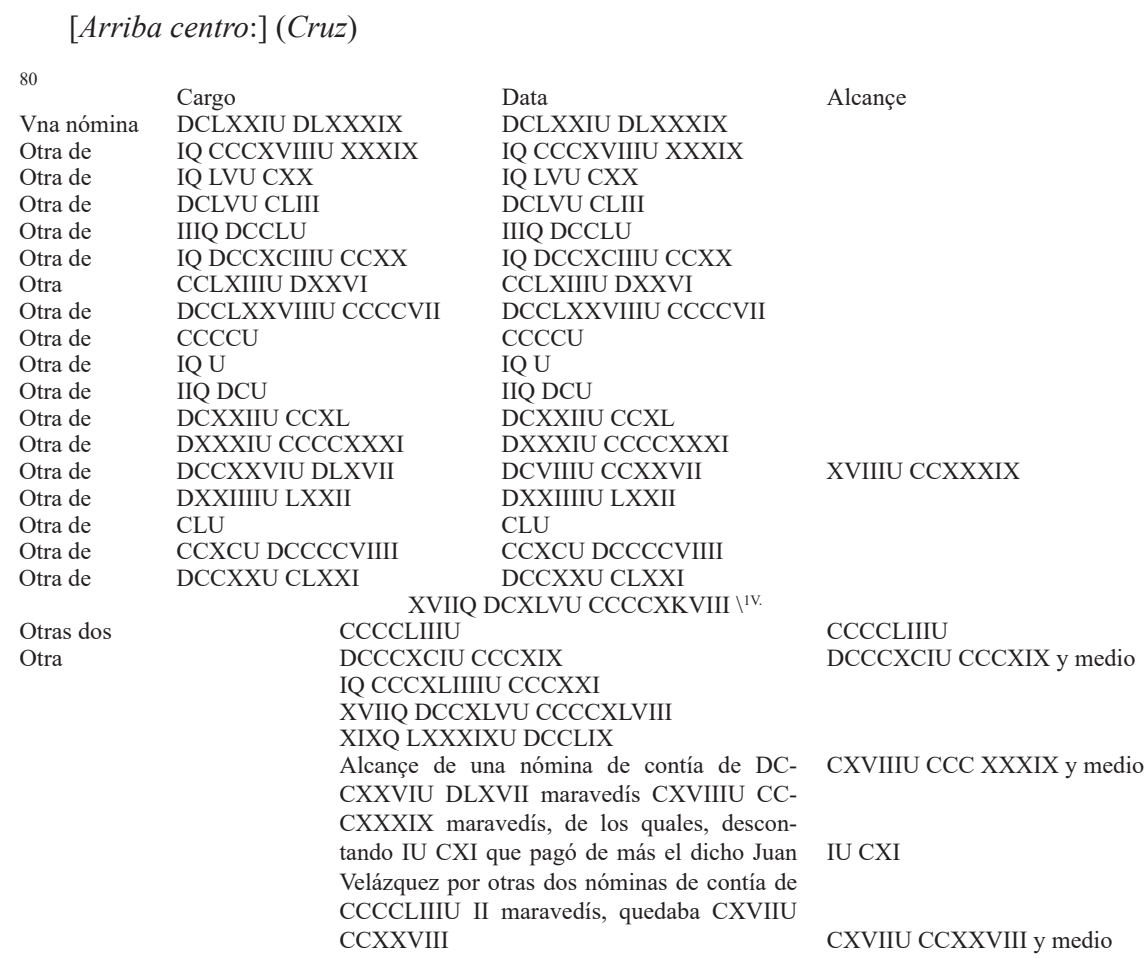

Ansi que montó el cargo de maravedís que fue fecho a vos, el dicho Juan Velázques, de todo el oro e plata e joyas e tapeçerías e ropas e otras qualesquier cosas que fueron vendidas en la manera e segúnd que en esta mi carta de finiquito está declarado XIX quentos LXXXIXU DCCLXIX y medio de maravedís, e montó las datas que fizistes para en descargo dellos, segúnd que ansý mismo en esta dicha mi carta de finiquito está declarado XviII quentos DCCCCLXXIIU DXLI y medio de maravedís ${ }^{81}$, de manera que fíncó de alcançe contra vos, el dicho Juan Velázques, çiento e diez e syete mill e dozientos e veynte e ocho maravedís, los quales avéys de dar e pagar a quien por mí vos fuere mandado, syn embargo desta mi carta de finiquito, e ${ }^{2 \text { 2r. }}$ otrosý, por quanto en esta dicha mi carta de finiquito vos fue fecho cargo de una corona e un collar ricos e de çiertas armas $e^{82}$ sedas e brocados e paños e lienços e perlas e aljófar e hornamentos e custodias, cáliçes e patenas, cruzes, portapazes e otras cosas de capilla, tapeçería, retablos, porcelanas, cosas de olicornio e copas e vasos e relojes e otras cosas de muchas calidades, e ropas de vestir de brocados, sedas e chamelotes, e

80. Tachado: Una nómina.

81. Tachado: que [ilegible]

82. Tachado: ropas. 
paños e fustedas e estameñas que se deshizieron para haser hornamentos, lo qual todo que dicho es no se vendió ni ovo de vender. A vos, el dicho Juan Velázques, que se las distes y entregastes, por mandado del rey, mi señor e padre, a las personas e segúnd y en la manera que en esta dicha mi carta de finiquito va espeçificado e declarado, por ende, sea entendido y entiéndase que de todas las dichas cosas que asý vos van puestas por cargo e descargo en esta dicha mi carta de finiquito, no queda ni finca contra vos, el dicho Juan Velázques, alcançe alguno, salvo solamente quedan a vuestro cargo otras cosas que por los mis libros de mi cámara paresçe que vos están cargadas, de que al presente no podistes dar ni fenesçer cuenta e la avéys de dar a los dichos mis contadores mayores de cuentas quando por ellos vos fuere pedida.

E agora, por quanto por parte de vos, el dicho Juan Velázques, mi qontador mayor e de mi qonsejo, me fue suplicado e pedido por merçed que, pues avíades dado la dicha quenta del cargo de los maravedís e cosas de suso en esta mi carta qontenidas, que a mi merçed pluguiese de vos mandar dar mi carta de finiquito o como la mi merçed fuese, e yo tóvelo por bien, por ende yo, la sobredicha reyna doña Juana, por esta mi carta de finiquito, leo e apruevo la dicha cuenta que asý vos fue tomada por los dichos mis qontadores mayores de cuentas e la he por buena, çierta e verdadera, e doy por ${ }^{2 \mathrm{2v}}$ libre e quito a vos, el dicho Juan Velázques e a las otras personas que por vos tovieron el dicho cargo e a vuestros bienes y herederos e suçesores, para agora e para sienpre jamás, e quiero e me plase que contra vos ni contra ellos no me quede ni finque derecho, açión ni otro recurso alguno por rasón del dicho cargo, e mando a los dichos mis qontadores mayores de quentas e a sus lugartenientes que agora son o serán de aquí adelante que vos no llamen ni fagan llamar a vos ni a ellos para que les ayáys de dar otra vez la dicha quenta, e sy vos llamaren, que no seáys ni sean obligados a venir ni paresçer ante ellos, e que por lo asý fazer no cayáys ni yncurráys en pena alguna, e, otrosý, por esta dicha mi carta mando a todas e qualesquier mis justiçias destos mis reynos e señoríos que vos guarden e cunplan e fagan guardar e cunplir esta dicha mi carta, e que contra el thenor e forma della vos no vayan ni pasen ni consientan yr ni pasar en tiempo alguno ni por alguna manera, so pena de la mi merçed, e por quanto demás de las cosas de ${ }^{83}$ que vos fue fecho cargo en esta mi carta de finiquito vos reçebistes otras cosas de la dicha cámara de la reyna, mi señora madre, de las quales no podistes al presente dar quenta por no averlas acabado de fazer vender e destribuyr, no se vos fizo cargo ni descargo de lo en esta dicha mi carta de finiquito, porque no se da syno de las cosas en él contenidas, e queda que avéys de dar de lo demás segúnd e como la avéys dado de lo contenido en esta mi carta de finiquito, e desto vos fue dada mi carta de finiquito, firmada del rey don Fernando, mi señor e padre ${ }^{84}$, administrador e governador destos mis reynos e señoríos, e refrendada de uno de los secretarios e sellada con mi sello de çera colorada e librada de los dichos mis qontadores mayores de cuentas e de sus lugartenientes, la qual va entre ziertas fojas de papel. Dada en la çibdad de Logroño, a [en blanco] días del mes de dizienbre del año del nasçimiento de nuestro Señor Ihesuchristo de mill e quinientos e dose años.

\section{BIBLIOGRAFIA}

Calderón Ortega, José Manuel (2001), Felipe el Hermoso, Madrid.

Clemencín, Diego (2004), Elogio de la reina católica doña Isabel, Granada.

83. Tachado: v.

84. Tachado: e. 
Domínguez Casas, Rafael (1993), Arte y etiqueta de los Reyes Católicos. Artistas, residencias, jardines y bosques, Madrid.

Fernández, Luis (1980), "El hogar donde Iñigo de Loyola se hizo hombre”, Archivum Historicum Societatis Iesu 49, 21-94.

Fernández, Luis (1981), Los años juveniles de Íñigo de Loyola: su formación en Castilla, Valladolid.

González Marrero, María del Cristo (2005), La casa de Isabel la Católica. Espacios domésticos y vida cotidiana, Ávila.

Ladero Quesada, Miguel Ángel (1998), "La Casa Real en la Baja Edad Media", Historia, Instituciones, Documentos 25, pp. 327-350.

Ladero Quesada, Miguel Ángel (2016), Los últimos años de Fernando el Católico (1505-1517), Madrid.

Ladero Quesada, Miguel Ángel (2017), Francisco de Vargas, tesorero real: un testimonio sobre los últimos años de Fernando el Católico 1506-1517, Madrid.

Martín Barba, José Julio (2018), "Identificación de un libro propiedad de Isabel la Católica: el Smaragdo de la catedral de Córdoba", De medio Aevo, 12, pp. 13-46.

Pérez Álvarez, Víctor (2013), "Mechanical clocks in the medieval Castilian royal court", Antiquarian Horology, 34, pp. 489-502.

Pérez Álvarez, Víctor (2015), "From Burgundy to Castile. Retracing and reconstructing a fifteenth-century golden clock", Antiquarian Horology, 36, pp. 249-254.

Rodríguez Villa, Antonio (1909), “Un cedulario del Rey Católico (1508-09)”: Boletín de la Real Academia de la Historia 54, pp. 373-412; 518-525; 55, pp. 137-272; 325-352; 369-402.

Ruiz García, Elisa (2004), Los libros de Isabel la Católica: arqueología de un patrimonio escrito, Madrid.

Ruiz García, Elisa (2005), "Entre la realidad y el mito. Los auténticos libros de Isabel la Católica" en: Checa, Fernando; García, Bernardo (eds.), El arte en la Corte de los Reyes Católicos. Rutas artísticas a principios de la Edad Moderna, Madrid, pp. 355-371.

Rumeu de Armas, Antonio (1974), Itinerario de los Reyes Católicos. 1474-1516, Madrid.

Sánchez Cantón, Francisco Javier (1930), "El retablo de la reina Católica”, Archivo Español de Arte y Arqueología 6, pp. 97-133.

Sánchez Cantón, Francisco Javier (1950), Libros, tapices y cuadros que coleccionó Isabel la Católica, Madrid.

Suárez Fernández, Luis (1990), Los Reyes Católicos. El camino hacia Europa, Madrid.

Sevilla González, María del Carmen (2016), "Las nupcias de Catalina de Aragón. Aspectos jurídicos, políticos y diplomáticos", Anuario de Historia del Derecho Español, 86, pp. 657-726.

Testamento y codicilo de la reina Isabel la Católica (12 de octubre y 23 de noviembre de 1504) (2013), Madrid. 
Torre, Antonio de la (1974), Testamentaría de Isabel la Católica, Barcelona.

Zalama, Miguel Ángel (2005a), "Fernando el Católico y las artes: pinturas y tapices", Revista de Estudios Colombinos 11, pp. 7-28.

Zalama, Miguel Ángel (2005b), "Isabel la Católica y las joyas. La custodia de la catedral de Toledo" en: Checa Cremades, Fernando (ed.), El arte en la Corte de los Reyes Católicos. Rutas artísticas a principios de la Edad Moderna, Madrid, pp. 331-353.

Zalama, Miguel Ángel (2006a), "Valoración y usos de las artes. Colón y las joyas de Isabel la Católica" en: Checa Cremades, Fernando (dir.), La materia de los sueños. Cristóbal Colón, Valladolid, pp. 49-59.

Zalama, Miguel Ángel (2006b), "La corona y el collar de Isabel la Católica y la financiación del primer viaje de Colón" en: Varela Marcos, Jesús; León Guerrero, $\mathrm{M}^{\mathrm{a}}$ Monserrat (eds.), Cristóbal Colón, su tiempo y sus reflejos (Actas del Congreso Internacional $V$ Centenario de la muerte del Almirante en Valladolid), Valladolid, pp. 303-317.

Zalama, Miguel Ángel (2006c), "Felipe I el Hermoso y las Artes" en Zalama, Miguel Ángel; Vandenbroeck, Paul, Felipe I el Hermoso. La belleza y la locura, Madrid, pp. 17-50.

Zalama, Miguel Ángel (2008), "La infructuosa venta en almoneda de las pinturas de Isabel la Católica", BSAA arte 74, pp. 45-66.

Zalama, Miguel Ángel (2010), Juana I. Arte, poder y cultura en torno a una reina que no gobernó, Madrid.

Zalama, Miguel Ángel (2014), “Tapices donados por los Reyes Católicos a la Capilla Real de Granada", Archivo Español de Arte 87, 1-14.

Zurita, Jerónimo (1580), Los cinco libros postreros de la historia del rey don Hernando el Cathólico, de las empresas y ligas de Italia, Zaragoza. 